\author{
Žiga Pirnat \\ University of Ljubljana, Faculty of Arts
}

\title{
Genesis of the Genitive of Negation in Balto-Slavic and Its Evidence in Contemporary Slovenian
}

Genitive of negation is a Balto-Slavic syntactic rule that governs the transformation of accusative complements of transitive verbs or subjects of existential constructions in positive sentences to genitive complements in negative sentences. At present, this change is mandatory in Slovenian, Polish, and Lithuanian. In Russian, it is optional, while in other Slavic languages and Latvian, it is either considered archaic or extinct. The origin of the genitive of negation is usually derived from the ablative or partitive genitive case. The article advocates the latter and presents a model that derives the Balto-Slavic genitive of negation from the partitive genitive, which at a certain point acquired an emphatic meaning. According to the results of our empirical research, the original emphatic markedness of the genitive of negation is genetically and/or typologically reflected in contemporary colloquial Slovenian.

Rodilnik zanikanja je baltoslovanski skladenjski pojav, s katerim poimenujemo prestavo tožilniškega dopolnila prehodnih glagolov ali osebka v eksistencialnih konstrukcijah v rodilnik, kadar je glagolsko dejanje zanikano. Danes je ta prestava obvezna v slovenščini, poljščini in litovščini. $V$ ruščini je fakultativna, $v$ drugih slovanskih jezikih in latvijščini pa bodisi arhaična bodisi povsem izgubljena. Izvor rodilnika zanikanja nekateri povezujejo $\mathrm{z}$ ablativom, drugi pa s partitivnim rodilnikom. V članku zagovarjamo drugo možnost in v predstavljenem modelu rodilnik zanikanja razlagamo kot naslednik partitivnega rodilnika, ki je v določenem obdobju pridobil pomen emfatičnosti. Nekdanja emfatična zaznamovanost rodilnika zanikanja se po ugotovitvah empirične raziskave genetsko in/ali tipološko zrcali tudi v sodobni pogovorni slovenščini.

\section{Introduction}

Genitive of negation is a term encompassing all instances of the genitive case that are induced solely by the presence of a negated verb and correspond to non-genitive forms in affirmative constructions.

There are two basic types of such genitive. The first one relates to the subject of existential constructions that appears in the nominative in affirmative sentences and changes to the genitive when the predicate is negated (e.g., Slovenian Mojca $_{\text {nom. }}$ je doma 'Mojca is home' vs. Mojce ${ }_{\text {gen. }}$ ni doma 'Mojca is not home'). The second type 
affects direct objects of transitive verbs, which appear in the accusative in affirmative sentences and change to the genitive when the finite verb is negated (videl sem

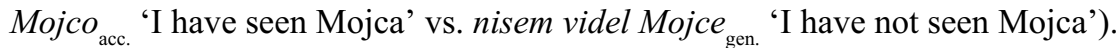

An interesting and typologically peculiar phenomenon, the genitive of negation does not only exist in Slovenian. As a mandatory syntactic rule, it survives in Old Church Slavonic (OCS), Polish, and Lithuanian. It is partially preserved in Russian, while many other Slavic languages and Latvian list it as a more or less archaic formation.

In the article, I focus on the genitive of negation of direct objects and-based on comparative and historical syntactic analysis - establish a diachronic model of its genesis from the partitive genitive and emphatic negation. In the empirical research that follows, I examine the usage of the construction in contemporary (spoken) Slovenian $^{1}$ and point out whatever (genetic or typological) traces/remnants of its original syntactic function can be found at the synchronic level.

\subsection{Genitive complement of negated verbs}

Genitive is the grammatical case used to express possession, affiliation, composition, origins, and other similar relationships between syntactic units. From a diachronic point of view, Balto-Slavic genitive is closely linked to the Indo-European ablative. In syntax, it corresponds to the Old Indian and Latin genitive and ablative. The historical semantic proximity and consequent merger are reflected in the genitive singular ending of the former thematic $\breve{o}$-stems in Balto-Slavic, which originates from the Indo-European ablative form. ${ }^{2}$

When categorizing the genitive case in Slavic languages according to its functions, Vondrák (1928) lists two "special genitive" types, in addition to the "true genitive" and "ablative genitive" (both groups with either adnominal or adverbal use). The former two outliers include the "genitive in negative sentences" and the "genitive-accusative", i.e., the use of the genitive ending instead of the accusative for animate nouns. ${ }^{3}$ Out of the three Vondrák's groupings, the two special types stand out the most, as neither negative constructions nor genitive-accusative offer an easy derivative explanation or categorization by adnominal or adverbal use.

${ }^{1}$ The research was part of the thesis Iztožilniški rodilnik ob zanikanih prehodnih glagolih $v$ baltoslovanščini (Pirnat 2011).

${ }^{2}$ In Lithuanian, the genitive singular ending of thematic $\breve{o}$-stems is $-o$, as opposed to the Slavic $-a$. As pointed out by Szemerényi $(1980,168)$, this implies a Proto-Balto-Slavic $*-\bar{a} d$ with an unexplained $\bar{a}$. Other languages attest reflexes of a Proto-Indo-European thematic ablative ending $*_{-} \bar{o} d$.

${ }^{3}$ Genitive-accusative originally only appeared in the accusative singular of animate masculine ŏ-stems and with the interrogative word $* k o g o_{\text {acc./gen. }}$ 'whom', replacing the former accusative form (which, in this case, was the same as the nominative). 
While it is possible to attribute the emergence of the genitive-accusative to a desire to avoid ambiguity in the subject-object relationship, negative constructions have proven to be much more challenging. Genitive of negation (Latin genetivus negationis, also called Slavic genitive) is a complex phenomenon; it involves rection transformation and can affect subjects of existential sentences as well as direct objects of transitive verbs. Moreover, it also appears with nonfinite verbs and dual objects. On the other hand, the government does not change with (indirect) objects in other cases: Slovenian odprli so vrata acc. 'they opened the gate' and niso odprli vratgen. 'they did not open the gate'; vs. pomagam sosed $u_{\text {dat. }}$ 'I help the neighbor' and ne pomagam sosed $u_{\text {dat. }}$ 'I do not help the neighbor'. Also, the case is not affected when a dependent noun clause serves as the object of a negative main clause: nisem hotel, da $v_{\text {vame pisalo }}$ acc. 'I did not want him/her to take the pen', nisem videl, kdo gradi hišo ${ }_{\text {acc. }}$ 'I did not see who was building the house'.

Sometimes, the sense of negation is so strong that it transcends the syntactic boundaries and transforms the rection even when the sentence is affirmative but has a "negative meaning". Miklošič $(1883,500)$ lists examples such as OCS zabyhb sъněsti hlěba moego ${ }_{\text {gen. }}$ 'I forgot to eat my bread', Slovenian varujte se vpričo ljudi delati svojih dobrih del ${ }_{\text {gen. }}$. 'beware of doing your good deeds in front of other people', Czech tobě jsem bránila tvého bludu $u_{\text {gen. }}$ 'I was protecting you from your delusion', Polish bała się ust ${ }_{\text {gen. }}$ otworzyć 'she was afraid to open her mouth'.

Genitive complement of negated transitive verbs is a distinctive feature of Baltic and Slavic languages. Some claim to have identified its traces in Gothic, Old High German, Old French, and Ancient Greek. There is a typological cognate in Finnish, where an accusative complement changes into the partitive when the governing transitive verb is negated.

\section{Genitive of negation in selected languages}

Modern Baltic and Slavic languages vary considerably in prevalence of genitive complements of transitive verbs. Historical analysis shows that the genitive government was most likely the only possible relationship between direct objects and negated verbs in the oldest stages of the Balto-Slavic branch. It later gradually started to be replaced by analogy with accusative forms from the corresponding affirmative sentences. In this chapter, the evidence in Slovenian and Russian is examined in detail, followed by a quick review of other Balto-Slavic and Non-Balto-Slavic languages. 


\subsection{Slovenian}

In Slovenian, the change in government of transitive verbs from accusative to genitive in negative sentences is mandatory (Toporišič 2004, 501):

\author{
Videl sem hišo \\ 'I saw the house' \\ Tam lahko slišiš ptice \\ 'You can hear the birds there' \\ Zelenjavo $o_{\text {acc. }}$ imam rad \\ 'I like vegetables' \\ Sram jo acc. je bilo same sebe \\ 'She was ashamed of herself'
}

\author{
Nisem videl hiše $e_{\text {gen }}$ \\ 'I did not see the house' \\ Tam ne moreš slišati ptic \\ 'You cannot hear the birds there' \\ Zelenjave $_{\text {gen }}$ nimam rad \\ 'I do not like vegetables' \\ Ni je $e_{\text {gen. }}$ bilo sram same sebe \\ 'She was not ashamed of herself'
}

Genitive object is not mandatory in compounds with correlative conjunction ne le (samo) - temveč (ampak, marveč) (tudi) 'not only - but also'. Nevertheless, it is possible: ${ }^{4}$ ni zaprla le vrat ${ }_{\text {gen. }}$ vrata $_{\text {acc. }}$, temveč tudi okno acc. 'she did not only close the door but also the window'. A similar exception applies to the negative pronoun nic 'nothing' and the non-specific indefinite pronoun kaj 'something (or other)': nič acc.' ničesar $_{\text {gen. }}$ ne vem 'I do not know anything', nič ${ }_{\text {acc. }}^{\text {. }}$ ičesar ${ }_{\text {gen. }}$ ne želim od tebe 'I do not want anything from you', nimam $\mathrm{kaj}_{\text {acc. }} / \mathrm{cces}_{\text {gen. }}$ obžalovati 'there is nothing I could regret' ${ }^{5}$ Unlike Toporišič, Breznik sees the accusative as the only correct case with objects in ne samo - temveč tudi constructions, as in such sentences, it is the object that is negated, rather than the predicate. Kaučič-Baša $(1982,306)$, on the other hand, argues that such stance fails to separate syntactic form from syntactic meaning: negation of any individual sentence unit in Slovenian is formally marked with a negated predicate and genitive object. Breznik's opposition to genitive objects in such constructions seems unjustified, as even he ultimately acknowledged that these conjunctions bewildered writers as early as a thousand years ago. In OCS, one can find both genitive and accusative objects in such constructions.

Toporišič mentions that negation can also influence the syntactic expression of the agent, which essentially applies to existential constructions. Genitive, however, is only acceptable with the verb biti 'to be' and some other verbs that express existence,

${ }^{4}$ Lithuanian, on the other hand, does not use the genitive of negation in this type of sentences. According to Mathiassen $(1996,185)$, in such cases, the negation does not affect the entire sentence but only a certain part of it: aš nusipirkau ne naują dvirati ${ }_{\text {acc, }}$, bet/o naują mašina $\mathbf{a}_{\text {acc. }}$ 'I have not bought a new bicycle but a new car', which — as shown next - is a dubious argumentation.

${ }^{5}$ Which is, interestingly enough, not the case in Russian. Even though its use of the genitive of negation is substantially weaker than in Slovenian, the Russian negative pronoun ničto 'nothing' always appears in the genitive form ničego when acting as complement of negated transitive verbs (Guiraud-Weber 2003, 367). 
presence, and location (pravica ${ }_{\text {nom. }} j e$ 'there is justice' vs. pravice ${ }_{\text {gen. }} n i$ 'there is no justice'; gospa $a_{\text {nom. }}$ je doma 'madam is home' vs. gospe ${ }_{\text {gen. }}$ ni doma; 'madam is not home'; prireditev nom. bo 'the event will happen ("be")' vs. prireditve $e_{\text {gen. }}$ ne bo 'the event will not happen').

The use of the genitive for the subject of other negated predicates is neither formal nor common: **ničesar ${ }_{\text {gen. }}$ se ni zgodilo 'nothing has happened' (correct: nič ${ }_{\text {nom. }}$ se ni zgodilo). The same is true for genitive subjects of passive constructions: **takih stvari $_{\text {gen. }}$ se ne govori na glas 'such things are not to be spoken out loud' (correct: take stvari $_{\text {nom. }}$ se ne govorijo na glas) (Toporišič 2004, 501). ${ }^{6}$ On the other hand, Miklošič $(1883,499)$ mentions several examples of this type: Slovenian starca $_{\text {gen. }}$ nestalo je 'the old man disappeared', brez božje volje ti ne izpade lasu ${ }_{\text {gen. }}$ 'without God's will, a hair will not drop from you(r head)'; Serbian broja $a_{\text {gen. }}$ se ne znade 'the number is not known'; and Russian takogo domu ${ }_{\text {gen. }}$ nigdě ne vidano 'such house has never been seen anywhere'.

Some authors (see Przepiórkowski 2000) make a distinction between local and long distance genitive of negation. While the first one refers to direct objects of finite transitive verbs, long distance genitive is assigned to complements of lower, usually infinite verbs when a higher finite verb of the construction is negated. In Slovenian, both types are mandatory: otrok ni pospravil sobe ${ }_{\text {gen. }}$ 'the child did not clean up the room', otrok ni želel pospraviti sobe ${ }_{\text {gen. }}$ 'the child did not want to clean up the room'. Dual objects are also affected: učitelj ne uči učencev $v_{\text {gen. }}$ matematike $e_{\text {gen. ' }} \mathrm{a} / \mathrm{the}$ teacher does not teach pupils Math'. The first accusative object changes to genitive "much more often than the second one" (Orešnik 1992, 37). It is therefore possible to say Janez ne poučuje Mojce gen. slovenščino acc. 'Janez is not teaching Mojca Slovenian', as well as Janez ne poučuje Mojce $e_{\text {gen. }}$ slovenščine ${ }_{\text {gen }}{ }^{7}$ A set of infinitives can be even longer; in such cases, long distance genitive of negation seems to be less frequent and the accusative form often the more acceptable government: starši niso hoteli siliti otroka $_{\text {gen. }}$ pospraviti igrače $e_{\text {acc. }} / * * i g r a \check{c}_{\text {gen. }}$ 'the parents did not want to force the child to put away the toys'.

\subsubsection{Historical overview}

Freising Manuscripts as the oldest (although scarce) written source of early Slovenian from the late tenth / early eleventh century show a consistent use of the genitive for objects of all attested negated transitive verbs: roti choi se $i h_{\text {gen. }}$ ne pazem 'oaths that we do not honor'; starost ${ }_{\text {gen. }}$ ne prigemlioki, nikoligese petsali ${ }_{\text {gen. }}$ ne

${ }^{6}$ Nevertheless, the accusative object can change to genitive if the subject is expressed in a general sense: takih stvari ${ }_{\text {gen. }}$ se vpričo mene ne bo omenjalo 'such things shall not be mentioned in my presence'. According to Toporišič $(2004,501)$, this form is particularly prevalent in the western Slovenia and, partially, in Ljubljana.

${ }^{7}$ At the same time, "[...] it is not even clear whether the second accusative [object] can actually change to genitive because of negation, as one also finds a non-negated [sentence type] Janez poučuje Micko [acc.] matematike $_{\text {[gen.] }}$ (Orešnik 1992, 37). 


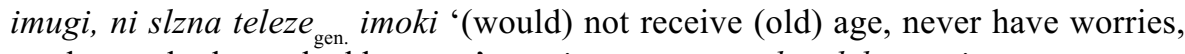
nor have a body marked by tears'; ese iezem ne zpazal nedela ${ }_{\mathrm{gen}}$, ni zueta vueceragen. ni mega pozta ${ }_{\text {gen. }}$ i inoga mnogoga $a_{\text {gen. }}$ 'because I have not honored Sunday, nor the Holy Evening, nor my fasting nor many other things' (see Freising Manuscripts: Digital Edition 2007).

Certain Slovenian dialects, however, have started losing the genitive of negation from very early on. Trubar (1508-1586) and Dalmatin (1547-1589) used it often, yet instances of accusative instead of the expected genitive forms can occasionally be found in their texts (Merše 2000, 218). In the first Slovenian grammar Arcticae Horulae succisivae, Bohorič $(1987 / 1584,322)$ does not mention the accusative-genitive transformation. Krelj (1538-1567) has a higher share of negative accusative objects than other Protestant writers. Direct objects of negated verbs in the genitive are almost completely absent from Svetokriški's (1647-1714) works (Merše 2000, 218). Cf. Trubar: ne fte nigdar, ne nega ftyme ${ }_{\text {gen. }}$ slishali, ne nega oblizhia ${ }_{\text {gen. }}$ uidili 'you have never heard his voice nor seen his face'; Criftus ne hozhe to Preshuftnizo acc. obfoditi 'Christ does not want to condemn the adulterous woman'; Dalmatin: Obene druge rizhy ${ }_{\text {gen. }}$ fe néma hvaliti, ni bogat ni vbogi 'of no other thing can he boast, neither the rich nor the poor'; NEraspihuj Pregréfhnimu njega ogin acc. 'do not inflame the fire of the sinful'; Krelj: Kijr pak Boshijo befedo acc. ne poflufha 'he who does not

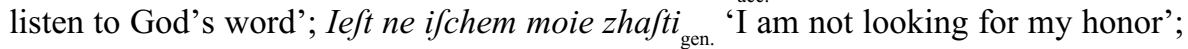
and Svetokriški: sakaj neufamesh en mezh acc. $_{\text {inu ferce }}$ acc. fi neprebodesh? 'Why do you not take a sword and thrust it into your heart?' (ibid.).

Pohlin does not explicitly refer to the genitive of negation either. He incidentally mentions it in another context: "Verbs of shortage are specifically employed with the $2^{\text {nd }}$ ending. Nimam starshov ${ }_{\text {[gen.] }}$ Meni dnarjov ${ }_{\text {[gen.] }}$ manka. Kruha $_{\text {[gen.] }}$ stradash?" 'I do not have parents. I am lacking money. Are you hungering for bread?'. On the very next page, however, he gives an example "Katire svoje starshe ${ }_{\text {[acc.] }}$ na wuga, je brez Boga" 'he who does not obey his parents is without God' (Pohlin 1768, 142-143). Metelko's grammar $(1825,242-243)$, on the other hand, defines the genitive of negation as a rule: $»[\ldots]$ to mark passive [i.e., direct] objects, verbs use genitive instead of accusative especially often; to be specific: 1) in all negative sentences [underlined by Ž.P.]"'. Metelko adds that there are exceptions, such as "word kaj, kar, nékej in nəč, especially when used indefinitely [...]: $k a j_{\text {[acc.] }}$ to pa né hôtel povédatə?" "what was it that he did not want to tell you?'. "Formerly, the increasingly rare [genitive form of kaj, kar, nékej in nəc̆] nəčésar used to be more common in all such negative sentences". Kej (standard kaj) 'what, something, anything' is mentioned as being especially averse to changing to genitive when being part of an infinitive construction and meaning nəč (standard nič) 'nothing, anything': némamo kej délatə; némam kej jestə 'we have nothing to do; we have nothing to eat'. Metelko adds that the change in government from genitive to accusative does not affect a clause without a verb, connected to a preceding clause with the conjunction kakor 'as, than' or ampak 'but': druzəga ${ }_{\text {gen. }}$ ne vidom, kakor kamne ino parst ${ }_{\text {acc. }}$ 'I do not see anything other than rocks and soil". 
One of the first analytical works focusing on the genitive of negation in Slovenian was Breznik's discussion about sentence negation. ${ }^{8}$ Based on examples from Slovenian literature and comparative method, Breznik described where the use of the genitive of negation was correct and where not. Accordingly, genitive of negation in Slovenian appears a) in first direct objects, b) in second direct objects, c) in complements to the infinitive (long distance genitive of negation), and d) in subjects of negated existential constructions with the verb biti (Breznik 1942; in Kaučič-Baša 1982, 305).

\subsubsection{Declining usage}

In contemporary spoken Slovenian, the genitive of negation is increasingly being ousted by the accusative. The coexistence of the two forms does not imply any semantic distinctive function (unlike in Russian). Rather, it is a result of analogy and leveling of this specific syntactic feature that is more or less archaic or has been completely replaced with accusative in many other Slavic languages.

\subsection{Russian}

In Russian, a negated transitive verb can have a genitive or accusative complement: ja ne pisal pis' $m a_{\text {gen. }} /$ pis' $^{\prime} m o_{\text {acc. }}$ 'I was not writing a letter'. In affirmative sentence (as in ja pisal pis'mo), genitive is not possible, with the exception of certain "intensional verbs" (see below). There is a general tendency to replace the genitive with the accusative; however, unlike Slovenian, the distribution of both cases in Russian is subject to a number of parameters, to the point that using one or another can change the meaning of a sentence. The process of the construction gradually becoming obsolete is "halfway through" in contemporary Russian. ${ }^{9}$ The accusative "statistically prevails and $[\ldots]$ represents the normal form of the direct complement in negative sentences" (Guiraud-Weber 2003, 365-366). Its usage is constrained by certain situations in which the genitive is mandatory, mostly:

- In fixed expressions, e.g., ne obraščat' vnimanija 'to not pay attention to', ne pridavat' značenija 'to not attribute importance to', ne igrat' roli 'to play no role';

- With negated verb imet' 'to have';

- In emphatic negation.

${ }^{8}$ Breznik, Anton. 1943. Stavčna negacija v slovenščini. In Razprave 1, ed. by Fran Ramovš, 157-200. Ljubljana: Akademija znanosti in umetnosti.

${ }^{9}$ Unlike the genitive of negation of direct objects, the genitive of negated existential constructions is widespread in Russian, even more than in other Slavic languages: otvet ${ }_{\text {nom. }}$ iz polka ne prišel ${ }_{\text {m.sg. }}$ 'the answer from the regiment has not arrived' in addition to otveta ${ }_{\text {gen. }}$ iz polka ne prišlo ${ }_{\text {n.s. }}$. Negated passive sentences, such as moroza $a_{\text {gen }}$ ne čustvovalos ${ }_{\text {n.sg. }}$ 'the cold was not felt', are also used (Borschev \& Partee 1998, 2-3). 
The accusative case is mandatory in sentences with weak negation, especially in infinitive constructions, and in cases when negation does not refer to the object, but to its quality: Maša ne nahodit etu knigu interesnoj 'Maša does not find this book interesting'. Since these genitive- and accusative-only circumstances are far from encompassing all possible negative sentences, there is a "broad area of oscillation" (ibid.), an indication of an incomplete and on-going process of a language change.

The Russkaja Grammatika of 1980 still advocates the more traditional view that negated transitive verbs require genitive complement by default, regardless of the object's semantic role. According to this rule, accusative forms are only to be used with referential objects (Krasovitsky, Baerman, Brown \& Corbett 2011).

The Sintaksis russkogo jazyka of 1963 mentions the genitive of negation as one of three verbal genitive governments in Russian. The change from accusative to genitive in negative sentences is considered a "general rule with numerous deviations" (Šahmatov 1963, 325).

\subsubsection{Historical overview}

The genitive of negation in Russian has experienced a substantial decline in the last three centuries, with its development reminiscent of other Slavic languages that have lost the construction entirely. In Lomonosov's grammar of 1755, the genitive government of negated transitive verb was considered mandatory. According to Collopy (1998, 1-2), however, even that was likely a linguistic prescription rather than description, as works preceding the grammar had already contained many instances of accusative complements in negative verbal context.

The accusative-to-genitive transformation of direct objects in negative sentences was fully adhered to up until the late seventeenth and early eighteenth centuries when isolated instances of the accusative case started to appear as objects of negated transitive verbs, although it was not until the early nineteenth century that the accusative complements became a systematic phenomenon (Taubenberg 1958, 6; Borkovskij 1978, 327; and Bulaxovskij 1954, 349-350; in Krasovitsky et al. 2011, 574). The accusative frequency in negative sentences was then gradually rising, until the twentieth century when-especially in its second half - the use of the genitive of negation dropped substantially. Krasovitsky et al. $(2011,575)$ analyzed a corpus of Russian literary texts written from 1801 through 2000 and calculated the percentage shares of genitive and accusative government of negated transitive verbs. Their findings showed a steady increase of the accusative case frequency, from $11 \%$ of all complements in the early nineteenth century to $49 \%$ in the second half of the twentieth century. The results, however, only refer to the literary language; spoken Russian, on the other hand, most likely had a higher prevalence of the accusative. Texts from as early as the seventeenth century written in a style close to colloquial idioms of the time used accusative more often than texts written in a higher style (Safarewicz 1960, 126; in Timberlake 1975, 133).

One of the factors that have significantly affected the change in the government of negated transitive verbs in Russian was the aspect. Accusative objects have 
appeared much more frequently with perfective than imperfective verbs $(9 \%$ vs. $4 \%$ in the first half of the nineteenth century and $48 \%$ vs. $30 \%$ in the second half of the twentieth century). In the nineteenth and early twentieth century, the percentage share of accusative complements of negated perfective verbs increased significantly in comparison to imperfective verbs. Later, the aspectual influence faded as both imperfective and perfective verbs experienced a substantial increase of accusative government under negation (Krasovitsky et al. 2011, 581).

\subsubsection{Genitive/accusative variation in negative sentences}

The variation of genitive and accusative objects in negative sentences in modern Russian has been studied many times. Although even native speakers often disagree whether an object should appear in the accusative or the genitive (Kagan 2007, 153), many factors have been suggested to influence the distribution of both cases.

In his research, Korn (1967) analyzed a corpus of Russian texts from the 19461964 period and concluded that the volatile usage of the genitive and accusative in negative context is mostly the result of grammatical prescription. "The genitive is stubbornly maintained against the more 'natural' accusative, because it is 'more correct'." (Korn 1967, 449) Nevertheless, he finds out that the accusative appears more frequently when the negated verb in question is perfective or in imperative mood, when the use of the genitive could result in ambiguity, and when the complement is topicalized.

Bailyn (2003, 15-16), on the other hand, argues that the genitive of negation in Russian is not optional, but rather an obligatory, configurational case. According to him, there are significant semantic differences between genitive and accusative negative constructions with the former implying an existential or indefinite reading and the latter an individuated, topical, or definite semantic value.

A different explanation is provided by Kagan (2007, 148-164), who compares the genitive of negation with the "intensional genitive", arguing that both cases depend on existential commitment. Kagan defines the intensional genitive as the phenomenon when certain intensional verbs ${ }^{10}$ appear with both accusative and genitive complements, in negative as well as affirmative sentences: on $\check{z} d a l \check{c} u d a_{\text {gen. }} / D i m u_{\text {acc. }}$ 'he was waiting for a miracle/Dima'; ty zasluživaeš medali ${ }_{\text {gen. }}$ medal' ${ }_{\text {acc. }}$ 'you deserve a medal'. The genitive government of intensional verbs in affirmative statements in Russian is mandatory in some cases while optional or ungrammatical in others. When the object is a proper name or appears with certain intensional verbs, such as predvidet' or predstavljat', the case marking is always accusative.

The two genitive types share several similarities: they both experience genitive/ accusative variation and follow similar hierarchies, including existential commitment.

${ }^{10}$ Including xotet' 'to want', želat' 'to wish, have a desire for', žaždat' 'to thirst for', trebovat' 'to demand', prosit' 'to ask for', ždat' 'to wait for', ožidat' 'to wait for, to expect', iskat' 'to search for', izbegat' 'to avoid', zasluživat' 'to deserve', stoit' 'to cost, be worth', bojat'sja 'to be afraid of'. 
Dima ne našël sledy ${ }_{\text {acc. }}$ and Dima ne našël sledov ${ }_{\text {gen. }}$ 'Dima did not find (the) traces' have different meanings: either that Dima did not find the traces (that actually existed) or, in the second sentence, that Dima did not find any traces (because there were none). Moreover, the accusative does not always imply an existential commitment, whereas the genitive rules out any such possibility.

Kagan argues that both genitive types are a single phenomenon, which she labels as Irrealis Genitive. Case marking of this construction thus depends on the existential commitment: an object only appears in the Irrealis Genitive if it does not have an existential commitment in the actual world or in any other alternative version of reality. In her later work, Kagan (2010) expanded the concept of the Irrealis Genitive to include the partitive genitive. While this definitely reinforces the concept with a vital component, it seems that more attention should be given to a diachronic view of how these three types evolved, as their historical syntactic relationship is the primary reason for today's correlation.

\subsubsection{Timberlake's concept of individuation}

Timberlake $(1975,124-135)$ relates the differences in accusative/genitive complement distribution in Russian to the individuation of the participant, which is in inverse relationship with the genitive of negation. The more the participant (i.e., the complement) or event is individuated, the less likely it is to appear in the genitive under negation. The degree of individuation is reflected in several semantic, syntactic, and other linguistic hierarchies, including proper vs. common, concrete vs. abstract, count vs. mass, animate vs. inanimate, singular vs. plural, definite vs. indefinite, neutral vs. emphatic, topicalized vs. neutral, etc. Each of these hierarchies contrasts two different levels of individuation with different likelihoods of a transitive verb being employed with the genitive case under negation.

Concrete complements, for example, are more individuated than their abstract counterparts, which inherently cannot be individuated. As such, the former are less likely to appear in the genitive according to Timberlake:

Ne slušaj ego - on ne dast tebe horošij sovet ${ }_{\text {acc. }}$ (Acceptable, but not preferred)

Ne slušaj ego - on ne dast tebe horošego soveta ${ }_{\text {gen. }}$ (Normal and preferred)

'Do not listen to him, he will not give you good advice'

Ne pokupaj u nego - on ne prodast tebe horošee plat' $e_{\text {acc. }}$ (Normal and preferred)

Ne pokupaj u nego - on ne prodast tebe horošego plat' ${ }^{\text {acc. }} a_{\text {gen. }}$ (Acceptable, but not preferred)

'Do not buy (things) at his place, he will not sell you a good dress'

Complements modified by a marker of emphatic negation (such as nikakoj, ni odin, $n i$ 'none whatsoever, not a single one, neither') cannot be individuated as they indicate a general and nonspecific negation referring to each and every participant. In such cases, genitive is mandatory: 
Ja ne čitaju gazetu (Normal and preferred)

Ja ne čitaju gazety (Marginally acceptable)

Ja ne čitaju nikakuju gazetu (Unacceptable)

Ja ne citaju nikakoj gazety (Normal and preferred)

'I do not read (any) newspaper (at all)'

The genitive supposedly refers to the extent to which a participant is involved in the event, rather than to the participant itself, and therefore represents a quantification of participation (Jakobson 1971, 38; in Timberlake 1975, 127) - the inverse of individuation. Negation to a certain extent excludes the participant from participation, with the genitive indicating that the extent of participation is negative.

Timberlake also identifies some additional hierarchies that refer to different degrees of individuation/quantification, thus affecting the genitive/accusative frequency: infinitive vs. finite verb, perfective vs. imperfective, imperative and conditional vs. indicative, interrogative vs. declarative, secondary complement (dual object) vs. one complement, adverbial specification vs. direct object, lexical categories, formal vs. informal style, and second declension singular vs. other declensions. ${ }^{11}$

Timberlake's concept is one of the most comprehensive explanations of the Russian genitive/accusative variation in negative constructions from a synchronic point of view. As many other similar studies, it calls for an additional diachronic analysis that could link the hierarchies of individuation with the origins of the genitive of negation.

${ }^{11}$ This is explained by some as a desire to avoid ambiguity. Namely, if the genitive case

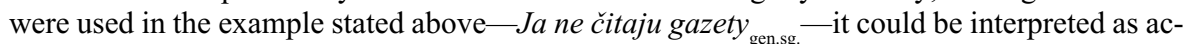
cusative plural. Timberlake $(1975,131)$ disagrees, pointing out the identical ambiguity that exists for (many) neuter nouns of the $\breve{o}$-declension (e.g., gen. sg. and acc. pl. čuvstva of nom. sg. čuvstvo 'feeling'). Yet all these nouns are more often used in the genitive when acting as direct objects of negated transitive verbs compared to the nouns of the $\bar{a}$-declension. Also, there is no ambiguity when an $\bar{a}$-declension noun is used with a modifier or with nouns of mobile accent paradigms that have different lexical stress for genitive singular and accusative plural. Timberlake is definitely correct in explaining the differences in accusative/genitive government tendency between nouns of different declensions through inherent features of the paradigms. Nevertheless, his reasoning seems to be less convincing when he focuses on the concept of individuation. The different occurrence of the genitive of negation in the nouns of the $\bar{a}$-and $\breve{o}$-declension can best be explained by the special role of the genitive case in masculine nouns. The genitive-accusative rule that historically replaced the accusative form of the animate masculine nouns (originally identical to the nominative) in the singular with the genitive, makes the genitive form, especially when used in direct objects, significantly more common in masculine than feminine nouns. While a genitive object in a negative sentence sounds relatively unusual with feminine nouns, it is much more acceptable with masculine nouns and less likely to be affected by analogical leveling. The syntactic connection between animate and inanimate nouns can be seen in Slovenian če boš priden, boš dobil bonbončka $a_{\text {gen./ac.ss. }}$ 'if you are good, you will get a candy', a type of animation of inanimate nouns that take the animate accusative (i.e., genitive) ending in informal, affectionate speech, usually when talking to small children. 


\subsection{Other Balto-Slavic Languages}

In OCS, genitive government of negated transitive verbs was mandatory: nikbtože otb vasb ne tvoritb zakona ${ }_{\text {gen. }}$ 'none of you creates the law'; ne imamb kbde sbbirati plodb moihs gen. $_{\text {. }}$ there is nowhere I can gather my fruits'. The genitive also appears in negated infinitive or participle constructions: ne imatb kbde glavy $y_{\text {gen. }}$ podbkloniti 'he cannot bend his head anywhere' (Vaillant 1977, 77). In connection with the conjunction eda and ne trkbmo 'not only', and in rhetorical questions, the accusative is used in both affirmative and negative sentences (Vondrák 1928, 252).

Despite the mandatory use of the construction, rare exceptions can be found in OCS as well, possibly influenced by the original Greek text in translation. Vaillant juxtaposes ne şkryvajte sebě şkrovišta $a_{\text {acc.pl. }}$ from Codex Marianus (eleventh century) and Codex Zographensis (late tenth or early eleventh century) with the genitive version (szkrovištb ${ }_{\text {gen.pl. }}$ ) in Codex Assemanius (early eleventh century) and Sava's book (eleventh century). At the same time, accusative regularly appears in constructions with da ne or ne da 'not to': da ne věr $Q_{\text {acc. }} S$ szziždotb, nъ da ... 'not to develop faith, but ...'. The genitive, on the other hand, can also affect temporal adverbs in negative constructions: ne vbzmože edinogo časa $a_{\text {gen. }}$ pobbdéti š mnojQ 'he could not stay up with me for more than an hour' (Meillet 1897, 154).

Vaillant, Vondrák, and Miklošič separately highlight the genitive rection of the OCS verb nenavidèti 'hate, despise' (see nenaviditb světa 'he/she hates the light'; nenaviždo takogo dara 'I despise such a present'; also Czech návidéti 'to love'; já cesty zlé nenávidim 'I do not like a bad journey'; Polish nienawidzę twojich żartów 'I hate your jokes'). Namely, the verb is a compound of another verb naviděti and the negative marker ne. What was once a negated verb, became a new lexical unit that kept the negative government.

Among the living languages of the Balto-Slavic branch, in addition to Slovenian and Lithuanian, genitive complements of negated transitive verbs are also mandatory in Polish, while in other languages they have been partly or completely lost. ${ }^{12}$

\subsubsection{South Slavic languages}

In Serbian and Croatian, the genitive of negation is optional and only rarely used. In the Croatian recension of Church Slavonic, accusative forms appear as an innovation replacing the genitive in complements (of negated and some affirmative) transitive verbs (Vince 2008, 623). In the first edition of the Grammar and Stylistics of Croatian or Serbian Literary Language of 1899, the genitive of negation is given a greater priority than in the second one from the year 1931. It is also mentioned as an optional case marking in negative sentences with the infinitive or $d a+$ present constructions. The Grammar of Croatian or Serbian Language of 1952 by Brabec, Hraste, and Živković no longer prioritizes any of the two cases in negative constructions, listing both as semantically equivalent (Menac 1979, 65-66).

${ }^{12}$ Macedonian and Bulgarian are not relevant in this regard due to their loss of case system. 
According to Jonke $(1952,124)$, the genitive of negation is more frequently used by older Croatian and Serbian writers. Both forms are considered correct, and the genitive is not mandatory in either regular or emphatic negation (Belić 1950, 224). Menac $(1979,66)$ concludes that in terms of "today's linguistic sense [in Croatian and Serbian language,] the accusative is an increasingly more common form in the function of the object complement of negated verbs. In the older periods of the language development [...] and in some older writers[' works], in Vuk Karadžić and his successors, the use of the Slavic genitive was certainly more frequent".

In a statistical analysis of written works from different time periods and regions of the Serbo-Croatian linguistic area, Gortan-Premk (1961, 135-148) discovers that in the older period (from Karadžić's time to World War I) the genitive complement appeared in $51 \%$ of all negated constructions with transitive verbs, compared to $17 \%$ in the younger period. An exception was the verb nemati 'to not have', which almost exclusively appeared with genitive complements (in Serbian and Croatian, nemati is used in negative existential constructions). Complements consisting of an indefinite pronoun, on the other hand, appear in the accusative. In both periods, the genitive of negation was found to be better preserved in the language of the authors from Bosnia and Herzegovina. ${ }^{13}$

Menac $(1979,68-76)$ points out that the distribution of accusative and genitive complements in negative sentences in Croatian and Russian is inversed. In an analysis of Russian literary works and their Croatian translations released after World War II, she finds a genitive-to-accusative ratio of 80:20 in Russian and an inverse ratio of 21:79 in Croatian.

According to Menac, there is no position in which a complement of a negated transitive verb would only appear in the genitive. On the other hand, there are numerous circumstances when accusative is used exclusively in such constructions. Neuter pronouns ovo, to 'this', ono 'that', što 'what, something', and ništa 'nothing' almost always appear in the genitive. When the object is definite (through linguistic means or content), it also appears in the accusative. Nisam vidio nered $a_{\text {gen. }}$ thus means 'I did not see (any) mess', whereas nisam vidio nered suggests a reading of 'I did not see the mess'. A genitive form in the second context would be considered emotional or archaic. Somewhat more frequent occurrence of the genitive was found in emphatic negation with ni, nikakav, nijeda 'not a single (one) (at all)', which appeared with the genitive of negation in $30 \%$ of all cases. The highest prevalence of genitive government was observed in the verb nemati that appeared with a genitive complement in $75 \%$ of all cases. An above-average retention rate can also be found in some fixed expressions, although they are not spared from accusative replacement either. Semantically, Menac links the genitive of negation in Croatian with emphatic negation, universality,

${ }^{13}$ Cf. Stevanović (1969, 197-198; in Menac 1979, 67), according to whom the use of the genitive of negation is more frequent in the central and western Serbo-Croatian dialects, whereas supposedly considered archaic and rare in the written and spoken language of the eastern regions. 
indefiniteness, and partitiveness. In addition to that, Vince $(2008,623)$ maintains that in modern literary Croatian, negative constructions with genitive, in cases where accusative would also be possible, are felt as "either dialectal and colloquial or a vestige of an old-fashioned, noble, select style".

\subsubsection{West Slavic languages}

In Czech, the use of the genitive in negative constructions very likely started declining as early as the second half of the sixteenth century, when the first accusative complement of a negated transitive verb is attested. A rapid decrease followed in the seventeenth and eighteenth century, eventually reaching a total elimination of the construction in the twentieth century. ${ }^{14}$ In modern Czech grammar, the genitive of negation can only be found in certain fixed expression with the negative marker ne or with particles of emphatic negation (such as $a n i$ ). In all other cases, the object appears in the accusative: neřekl ani slovo ${ }_{\text {acc. }}$ 'he did not even say a word'; ten film ${ }_{\text {acc. }}$ jsem nevidèl 'I have not seen this movie' (Guiraud-Weber 2003, 364). As pointed out by Timberlake $(1975,132)$, "the older generation of Czech speakers preserves the genitive of negation with emphatic negation and with existential or possessive verbs, but the younger generation uses the accusative even in these contexts".

Unlike most other Slavic languages, Czech also lost the genitive in negated existential constructions (e.g., nikdo ${ }_{\text {nom. }}$ tam nebyl 'no one was there'). The genitive case can only be heard today in some fixed expressions, such as nebylo po něm vidu ${ }_{\text {gen. }}$ ani slech $_{\text {gen. }}$ 'there was no trace of him (no sight nor sound)' (Guiraud-Weber 2003, 364). A few decades ago, there was a distinctive increase in occurrence of the genitive of negation in the Czech and Slovak dialect continuum, running from west to east, evident from a better preservation of the construction in the eastern Moravian dialects and especially, in Slovak, where genitive complements of negated verbs were much more frequent. Uhlár claimed that the local genitive of negation was more frequent than its long distance counterpart and appeared in approximately $80 \%$ of all negated transitive verb constructions in the analyzed Slovak literary works from the first half of the twentieth century (Uhlár 1933, 612-626).

In contemporary Slovak, the genitive of negation is considered archaic and is not widely used. Usually, it only appears when a partitive genitive would be possible in the corresponding affirmative sentence. It is more frequent when the negation is emphatic, i.e., reinforced with the pronouns nijaky, žiadny 'none (at all), not a single one' oranalogous to Czech — when negation uses the particle ani (Chlupíková 2011).

Polish, on the other hand, is similar to Slovenian in this regard, as all complements of negated transitive verbs appear in the genitive: ja nie cierpie twojich

${ }^{14}$ Vondrák $(1928,252)$ lists some rare surviving examples such as úřady nečiní lidí gen

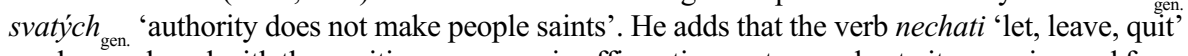
can be employed with the genitive case even in affirmative sentences due to its meaning and form (ne-) resembling the old genitive of negation constructions: nechejte toho ${ }_{\text {gen. }}$ 'stop that'. 
żartów ${ }_{\text {gen. }}$ 'I do not like your jokes' (Vondrák 1928, 252). Both local and long distance genitive of negation are present in Polish. The latter can comprise long infinitive sets,

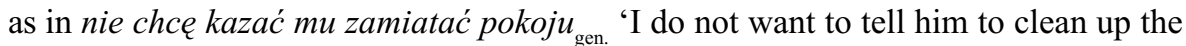
room'; nie musisz zamierzać przestać studiować algebry gen. 'you do not have to intend to stop studying algebra' (Przepiórkowski 2000, 3-4).

Similar to Slovenian and Lithuanian, accusative complements do not take the genitive case marking in negative sentences in Polish when followed by correlative conjunctions tylko or lecz 'but': kupiłam nie sukienke $e_{\text {acc.' }}$ tylko płaszcz ${ }_{\text {acc. }}$ 'I have not bought a dress, but a coat' (Błaszczak 2001, 58). On the other hand, Polish also transforms accusative forms in adverbial constructions to genitive when the verb is

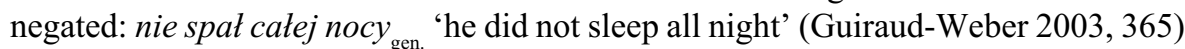
(note that in this case, the verb itself is intransitive).

The grammar of Upper Sorbian by Šewc $(1968,66)$ lists negation as one of the five genitive functions: njeméć chwile ${ }_{\text {gen. }}$ 'to not have a moment'; njeprajić ani stowa $_{\text {gen. }}$ 'to not say a (single) word'. The genitive of negation is moderately preserved in Lower Sorbian as well. Vondrák $(1928,252)$ lists several examples: Upper Sorbian nichto ani dna njenamaka 'no one finds the bottom'; Lower Sorbian wón ńejo stowicka styšat 'he did not hear a (single) word'. Nonetheless, in a more recent review of Sorbian languages, Schuster-Šewc $(2000,231)$ lists accusative along genitive forms: żanu nadziju némëjachu 'they did not have any hope (at all)'.

\subsubsection{East Slavic languages}

The Ukrainian Grammar of 1986 includes the so-called subject genitive in negated existential constructions (studentiv $v_{\text {gen. }}$ ne bulo $v$ zali 'students were not in the hall'). The work also mentions the object genitive, which supposedly appears with verbs that have an inherited lexical genitive government: vymagaty vidpovidi ${ }_{\text {gen. }}$ 'to demand an answer', and as partitive genitive: vypyty vody ${ }_{\text {gen. }}$ 'to drink (some) water'. It makes no mention of genitive occurrence that would solely depended on negation (Rusanovskij, Žovtobrjuh, Gorodenskaja \& Griščenko 1986, 58-59).

According to the Belarusian grammar of 1975, direct objects of transitive verbs can appear in the genitive when verbal action only encompasses a part of the object: pozna ŭnačy vjarnuŭsja Maksim, pryvëz troxi sena ${ }_{\text {gen. }}$ 'late at night, Maksim returned, bringing some hay'; or when the verb in question is negated: Nina nikoli ne bačyla getyx čaburekaŭ $\breve{g e n .}_{\text {. }}$ 'Nina has never seen these čebureks'; žyccë ne ljubic ' tlenu $u_{\text {gen. }}$ 'life does not love demise' (Adamovič et al. 1975, 52). Lukašanec, Prigodzič, and Sjameška $(1998,193)$ observe two circumstances in which the genitive use is declining in Belarusian: when indicating a time limitation (e.g., uzjac' scizoryka ${ }_{\text {gen. }}$ 'to take a knife (for a short time, couple of minutes)') and in connection with negated transitive verbs (e.g., ne ljubiŭ verša $\breve{\text { gen. }} /$ ver $\check{s} y_{\text {acc. }}$ 'he did not like poems'; ne zrabiŭ

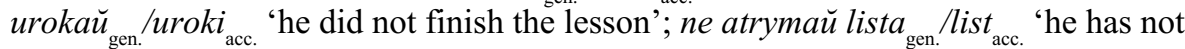
received the letter'). In both cases, the genitive use is considered archaic. 


\subsubsection{Baltic languages}

Genitive complements of negated transitive verbs, as well as affirmative transitive verbs when they denote a part of a whole (classified as the partitive genitive), can

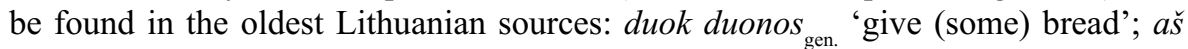
neturiu knygos ${ }_{\text {gen. }}$ 'I do not have the book' (Zinkevičius 1998, 176).

On the other hand, Meillet $(1897,153)$ claimed more than a hundred years ago that the grammaticalized genitive of negation was not characteristic of Lithuanian, which had supposedly "retained the liberty of using either the accusative or the genitive". According to him, the genitive had mainly appeared when the complement had a partitive value, whereby this was not a necessary precondition for the genitive. In all other cases, "the accusative ha[d] never ceased to be used: it ha[d] appeared since the earliest time" - and apparently still did at the time.

Contemporary Lithuanian, however, does not confirm these findings. Namely, the genitive of negation is a live and mandatory category in standard as well as spoken language: aš nusipirkau nauja stala ${ }_{\text {acc. }}$ 'I bought a new table' vs. aš nenusipirkau naujo stalo $_{\text {gen. }}$ 'I did not buy a new table'. As pointed out by Mathiassen $(1996,185)$, this rule is "strictly observed in Lithuanian".

The long distance genitive of negation also appears in Lithuanian (aš noriu pirkti $d_{\text {virati }}$ acc. 'I want to buy a bicycle' vs. aš nenoriu pirkti dviračio ${ }_{\text {gen. }}$ 'I do not want to buy a bicycle'), however, when there is "a longer distance" between the auxiliary and the infinitive, the accusative is also acceptable (nenoriu siandien eiti $\dot{k}$ parduotuve pirkti dviracio/dvirati 'I do not want to go to the store today to buy a bicycle'). ${ }^{15}$

Generally, the use of the genitive is more prevalent in Lithuanian than in Slavic languages. There is a reinforced partitive genitive function with many transitive verbs licensing either genitive or accusative complements (in affirmative sentences). A semantic distinction exists between the two forms: pirkti duonos ${ }_{\text {gen. }}$, sviesto $_{\text {gen. }}$, sürio ${ }_{\text {gen.' }}$, cukraus $_{\text {gen. }}$ ir miltu $_{\text {gen. }}$ 'to buy (some) bread, butter, cheese, sugar, and flour' vs. pirkti duonq $_{\text {gen. }}$, sviesta ${ }_{\text {gen. }}$, süri $\dot{g}_{\text {gen.' }}$ cukru gen. $_{\text {. }}$ ir miltus $_{\text {gen. }}$ 'to buy (all) the bread, butter, cheese, sugar, and flour (that is available)'. In such constructions, the genitive indicates that only a part of the object is affected by the verbal action, while the accusative implies the verb encompasses the entire object, ${ }^{16}$ not unlike the indefinite vs. definite opposition in other languages, such as English.

${ }^{15}$ Nonetheless, the use of the long distance genitive of negation varies across the regions. According to Skardžius, Barzdukas, and "other authorities on Lithuanian" (in Malcius Bulota $1980,26)$ there are several subdialects that use the accusative instead of the genitive in such cases.

${ }^{16}$ An identical semantic distinction can be found in Slovenian: kupiti kruha $a_{\text {gen. }}$ moke $e_{\text {gen. }}$ vs. kupiti $_{\text {kruh }}{ }_{\text {acc. }}$ moko $o_{\text {acc. }}$ 'buy (some) bread, flour'. The partitive genitive, however, is considered archaic and has been entirely ousted by accusative in informal speech. Unlike in Russian, in which the partitive function in such constructions is still preserved but mostly limited to perfective verbs: kupit ${ }_{\text {imp. }}$ hleb $a_{\text {gen. }}$ and kupit ${ }^{\prime}{ }_{\text {imp. }}$ hleb ${ }_{\text {acc. }}$ 'to buy (some) bread' but only pokupat ${ }_{\text {pf. }}$ $h l e b_{\text {acc. }}$ 'to buy (out, once, all the, etc.) bread'. 
The logical subject of negated existential and related constructions appears in the genitive as well: zooparke nebuvo liütu ${ }_{\text {gen. }}$ 'in the zoo, there were no lions', tèvo ${ }_{\text {gen. }}$ nera namie 'the father is not home'. The change from nominative to genitive in negative sentences parallels the situation in Slavic. Lithuanian, however, can use the partitive genitive in affirmative existential constructions as well (Mathiassen 1996, 182-183), forming an identical semantic opposition to the one in the genitive/ accusative variation.

Unlike Slovenian, the genitive of negation is very well preserved in spoken Lithuanian and is almost never replaced with the accusative. ${ }^{17}$ Declining use can only be observed in emigrant Lithuanian communities that are faced with intense foreign language influences (see Malcius Bulota 1980).

The construction is much less preserved in contemporary standard Latvian and its central dialects, where genitive complements of negated verbs have virtually disappeared. While they can still be heard in some eastern dialects (possibly due to Slavic influence), elsewhere, they have fully been ousted by the accusative: standard Latvian ne-mazgā muti ${ }_{\text {acc. }}$ 'she is not washing her face' vs. namåzgà $m u{ }^{i} t{ }^{i} s_{\text {gen. }}$ in eastern Latvian dialects (Balode \& Holvoet 2001, 38). In traditional Latvian songs and poems (dainas), the genitive of negation is relatively frequent. In some dainas, especially from the eastern part of the country, the long distance form can also be found: $i r b j u_{\text {gen. }}$ šauti nemācēja 'you are not allowed to shoot partridges' (Gāters 1993, 108-110).

The evidence for Old Prussian is much less clear. An in-depth analysis is hampered by the linguistic structure of the surviving sources, predominantly translations. Furthermore, the authors of these texts were often not native speakers of the language, which makes it difficult or even impossible to infer deeper syntactic layers. Endzelin $(1944,137)$ only finds two examples of genitive complements next to a negated transitive verb in the Old Prussian corpus: quai niturrīlai (ainontin mìlinan adder senskrempūsnan adder) steison deicktas ${ }_{\text {gen. }}$ 'which shall not have a spot or a wrinkle, or anything like that' ${ }^{18}$ and nidraudieite steison! 'do not oppose them'. Otherwise, the accusative is the normal case of the verbal complement in affirmative and negative sentences: tans ni turri podingan acc. 'he does not have pleasure'.

\subsection{Non-Balto-Slavic Evidence}

Outside Balto-Slavic, the genitive of negation only appears sporadically and is usually poorly attested and/or explained. Abaev (1965, 68-79; in Cvetko Orešnik 1998, 77) even suggested that the use of the genitive and accusative in Slavic languages, including the genitive of negation, was heavily influenced by Ossetian. There is,

${ }^{17}$ Information provided by Prof. Jelena Konickaja from the University of Vilnius.

${ }^{18}$ Endzelin does not mention that in this specific example, the negated verb niturrilai is followed by a compound object made of three nouns, of which only the last one (deicktas) appears in the genitive, while the other two (ainontin mìlinan and senskrempüsnan) could either be in the accusative singular or genitive plural. 
however, little valid evidence to support such claims. It can be said with certainty that the genitive of negation as found in Balto-Slavic, a widespread and mandatory rule, does not exist in any other Indo-European language. Nevertheless, some cases are worth mentioning.

For example, there are several instances of genitive complements in negated sentences in Gothic: lamba ni habandona hairdeis ${ }_{\text {gen.sg. }}$ 'sheep not having a shepherd'; $n i$

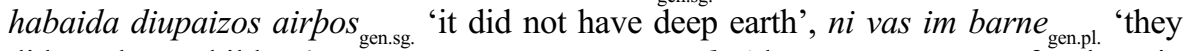
did not have children'; ni vas im rumis ${ }_{\text {gen.sg. }}$ in stada 'there was no room for them in the guesthouse'; barne $e_{\text {gen.pl. }}$ ni bileithai 'he does not leave the children' (Miklošič 1833, 501). All these examples are optional forms that sometimes have a specific semantic function as a marker of total negation: "[...] barne is the gen. pl., so that ni barne must be taken as equivalent to 'none of children', i.e. no child" (Skeat 1883, 55).

Furthermore, genitive government of negated transitive verbs is sometimes attributed to Ancient Greek (see Gāters 1993, 108), Old and Middle High German, and even Old French (see Uhlár 1933, 608). Nevertheless, the listed occurrences are isolated cases that are difficult to compare to the Balto-Slavic construction. A majority of them seems to be a type of genitive (mostly partitive) employed in negative sentences to give the negation an additional meaning. In most of the abovementioned languages, direct objects of transitive verbs in the genitive are also possible in affirmative sentences.

Moreover, genitive/accusative variation can imply definite/indefinite meaning. As pointed out by Abraham (1997; in Napoli 2010, 22), perfective verbs in Gothic and Old High German are employed with the accusative to suggest a definite reading, whereas their occurrence with a genitive complement always implies an indefinite object. Imperfective verbs, on the other hand, always appear with an accusative complement (at that stage, neither of the languages had a functional system of articles that would later take over the role of the (in)definite marker).

In all these cases, the genitive refers to a general, nonspecific, and indefinite quality of the object or action, a meaning that can be traced back to the historical partitive genitive. A typological parallel can still be found in French: je bois du vin 'I drink (some, a nonspecific, undefined quantity of) wine' vs. je bois le vin 'I drink the wine (that you brought me, etc.)'.

Whereas the genitive of negation seems to be a unique feature of the Balto-Slavic branch within the Indo-European family, there is a peculiar parallel in Finnish with a stable and fully developed system of a "partitive of negation" (Timberlake 1975, 135). A direct object changes its case marking from accusative to partitive when the governing verb is negated. The transformation is mandatory in the standard as well as spoken language.

The case of a direct object in Finnish can imply a particular aspectual reading, as aspect is not marked formally. Constructions with accusative complements suggest perfective reading, while those with partitive complements refer to imperfective reading (Comrie 1976, 8; in Krasovitsky et al. 2011, 580). Nonetheless, negated transitive 
verbs are always employed with the partitive case: Matti ei myynyt taloa $a_{\text {part. }}$ (as opposed to **talon ${ }_{\text {acc. }}$. 'Matti has not sold the house'. This rule sometimes even extends to adverbs (not unlike Polish and OCS): Matti ei odottanut tuntia ${ }_{\text {part. }}$ tunnin ${ }_{\text {acc. }}$ 'Matti did not wait for an hour' (Kiparsky 1998, 20-21). The case alteration also appears in infinitive constructions, a kind of long distance partitive of negation.

As the reconstructed case system of Proto-Ugro-Finnic has no partitive, its occurrence in Estonian and Finnish is sometimes attributed to foreign influence. As pointed out by Campbell $(1997,64)$, Balto-Finnic and Baltic languages share a wide array of partitive (genitive) case functions in addition to marking partial affectedness of the object, including the case of the subject in negative existential constructions and the object of negated transitive verbs. Nonetheless, relic constructions in the Balto-Finnic languages outside the area of possible Baltic influence (such as the languages of the Volga branch) imply an internal development in Finnish, according to Campbell.

On the other hand, the expansion of the case system in Lithuanian is definitely due to the Balto-Finnic influence. ${ }^{19}$ Furthermore, there is a widely held view in Russian historical grammar that the increased use of partitive genitive in Russian is due to the Russian-Finnish language contact (Kulikov 2006, 42). Speakers of Russian in Finland tend to preserve genitive objects of transitive verbs better than Russian speakers elsewhere (Leisio 2004). All this shows that a possible cross-linguistic influence- either way - should necessarily be considered as a viable option when discussing the genesis of the genitive of negation.

\section{Origins of the genitive of negation}

There are two likely explanations of where the Balto-Slavic genitive of negation stems from. The partitive origins theory is the most supported today. On the other hand, some link the construction to the old Indo-European ablative case.

Both explanations, however, leave many questions unanswered. Some of the issues that need to be addressed are the details of the shift from an original partitive (or ablative) meaning to a general and mandatory use in negative sentences regardless of the denotation, genitive/accusative usage variations, and possible semantic differences in instances when the object appears in either the accusative or genitive case. Relative chronology of the construction and potential external, Indo-European or Non-Indo-European influences also call for more research.

${ }^{19}$ There were three new cases introduced in the nominal inflection of Old Lithuanian: illative, allative, and adessive (Mathiassen 1996, 38). 


\subsection{Ablative origins theory}

Ablative explanation of the genitive of negation enjoys much less support today than it did in the past. ${ }^{20}$ Some of its proponents include Potebnja, Kudrjavskij, and Minkov (in Vondrák 1928, 251). The former bases his assumptions on the nature of negated verbs that are supposedly virtual, nonverbal, and auxiliary constructions. Vostokov interprets negation as a separation or abstraction from the verbal action, while Minkov concludes in his extensive study on the genitive of negation that its prevalence is a result of the Indo-European genitive/ablative syncretism ${ }^{21}$ (Potebnja; Vostokov; Minkov; in Uhlár 1933, 608).

Il'čenko (2010) is one of the few supporters of the ablative origins theory today. Her explanation employs the ablative as well as the partitive genitive, but she considers the genitive of negations' fundamental function to stem from the former. Accordingly, the partitive genitive in negative sentences originally implied incomplete transitivity, while the genitive of negation (derived from the ablative) indicated transitivity that had not occurred. Historically being an adnominal as opposed to adverbal case, the genitive could not have been the source of syntactic relationships according to Il'čenko, who also points out that the genitive of negation only appears in the IndoEuropean languages that have experienced the genitive/ablative merger. ${ }^{22}$

It is evident that all explanations linking the genitive of negation to the historical ablative necessarily involve complex inductive reasoning that more often than not seems vague and unconvincing. A separation of the complement from the verbal action is difficult to justify and might only be possible in a narrow semantic field, i.e., with only a few verbs. Šahmatov $(1963,325)$, for example, argues that while the origin of the construction is not completely clear, "the view of those who think that it is genitive-ablative must in any case be rejected."

${ }^{20}$ See Ladislav Hrovat's (1862) Slovenski genitiv, which argues that speakers of Slovenian conceive a separation of object and action in negative sentences, as the negated transitive verb does not extend to or reach the object.

${ }^{21}$ Minkov (in Uhlár 1933, 610-612) also argues that the phonetic insufficiency of the negative particle $*_{n e}$ has led to tendencies toward syntactic reinforcement of negation ever since the Proto-Indo-European era. This can be seen in many daughter languages: English not $(=n a+$ wiht $)$, German nein $(=n e+e i n), n i c h t(=n e+$ waicht $)$, Latin non $(=n e+u n u m)$, and especially French, in which the negation was reinforced with the connegative pas. In the same manner, Minkov explains the genitive of negation: as a desire to strengthen the negative meaning. Although Minkov's explanation of the relationship between the genitive of negation and ablative is not convincing, the concept of reinforcing the negative markers is indispensable in explaining genitive complements of negated verbs.

${ }^{22}$ It still seems, however, that defining the ablative-genitive merger as the requirement for the emergence of the genitive of negation is a doubtful conclusion. One needs only to consider the substantial morphological and semantic proximity of the two cases already existing in the proto-language, with only a handful of daughter languages preserving them as two independent cases. Furthermore, numerous non-Balto-Slavic languages that have merged the two cases have not developed constructions resembling the genitive of negation. 


\subsection{Partitive origins theory}

Partitive genitive is most common in constructions with quantitative markers referring to a part of something: Slovenian vedro vode ${ }_{\text {gen. }}$ 'a bucket of water', kup sena ${ }_{\text {gen. }}$ 'a stack of hay'. Some go further in discerning partitive from pseudo-partitive constructions, as only the former actually imply a part of something, while the latter actually refer to an amount of something: a piece of the cake vs. a piece of cake (Napoli 2010, 23).

In general, the partitive genitive refers to an indefinite and nonspecific quantity that is non-referential. A genitive complement of a transitive verb suggests that the verbal action does not extend to the entire notion of the complement, which is only partially involved in it (Ivšić 1970, 354). Nevertheless, such object is still indefinite

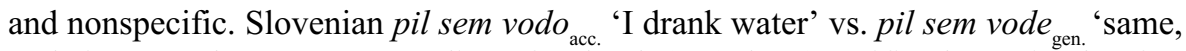
archaic' may also suggest a reading of 'I drank (out) that (specific, determined, referential amount of) water' in the first sentence and 'I drank some water (a nonspecific amount of the liquid as such)' in the second one.

Meillet $(1897,154)$ claims that the partitive genitive became obsolete in OCS ("vieux-slave") with the genitive subsequently losing its semantic contrast to the accusative in negated sentences. He uses the example of the negative pronoun ničbto 'nothing' as evidence confirming that the accusative used to be an acceptable rection of negated transitive verbs in OCS, as "it seems that the author of the original translation of the gospel considered it the correct form, and it only later started to be replaced with [the genitive form] ničeso". What Meillet fails to explain are the many instances of the partitive genitive in OCS, as well as the (preserved) partitive genitive in contemporary Russian and remnants of the construction in other Slavic languages. If its loss in fact occurred, which subsequently resulted in a new grammatical category, how can these (later) occurrences be explained?

There are further instances of negated verbs with accusative complements in the earliest stages. In addition to the negative pronoun ničbto, enclitic forms of personal pronouns are another example of accusative forms in negated constructions that can be found in the oldest OCS records: bljuděte se vraga da ne nagy sъtvoriţ vy acc. adama 'beware of the devil so he does not make you naked as (he did with) Adam'; ne azb li te $e_{\text {acc. }} v i d e ̌ x b ~ v b$ vrztě ss ńimb 'have I not seen you in the garden with him'. The same holds true for the reflexive pronoun under negation: ne ubojo sje 'I do not fear' (Meillet 1897, 154-155). On the other hand, accusative pronominal forms also occur in supine constructions, which normally consist of genitive complements regardless of negation: pridoms poklonitb $s \boldsymbol{e}_{\text {acc. }}$ emu 'we have come to pay tribute to him'. The accusative appears in nominal complements as well: ne pridohb pravedniky prizvatb vs. ne pridohs prizvats pravbdbnyhs 'I have not come to call the righteous' (Miklošič 1883, 500).

Obviously, the genitive was the original case in supine constructions, while instances of accusative forms in OCS are later innovations. In the same manner, accusative complements of negated transitive verbs in early OCS should not automatically 
be considered vestiges and evidence of a late genitive replacement, but rather a beginning of syntactic leveling process, eroding a previously clear cut distinction between accusative rection in affirmative context and genitive rection in negative context. While pronominal forms might indeed reflect a much older stage when accusative was still acceptable, the rare few cases of nominal accusative complements appearing under negation, pointed out by Meillet $(1897,154-155)$, can also be interpreted as early examples of analogous replacement.

According to Miklošič $(1883,498)$, the partitive origins of the construction are evident from the "strength of negation, as the action expressed by the verb is negated in its entirety and in each [individual], even the smallest part". Grimm, Pott, and-in the case of Gothic - Löbe and Gabelentz (in ibid.) hold the same view, as does Vondrák $(1928,251)$, who was one of the first to compare it with the Finnish "partitive of negation" mentioned earlier.

Advocates of the partitive origins usually explain the occurrences of the construction in non-partitive context through analogy. Meillet $(1897,153)$ argues that the genitive of negation is partitive only from a diachronic perspective, citing the Ancient

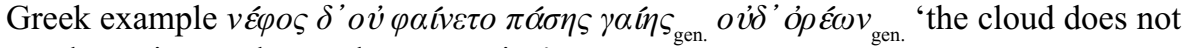
see the entire Earth, nor the mountains'.

\subsection{Genesis of the genitive government in negation - a diachronic model}

There are three basic questions that need to be addressed in order to explain the genesis of the genitive of negation in Balto-Slavic languages:

- Was the construction inherited from Proto-Indo-European, or did it appear later? If the latter is the case, at what development stage of Balto-Slavic and where did it first occur?

- Is the phenomenon an original innovation or a syntactic loan?

- What was its original semantic and/or syntactic motivation?

The documented phasing out in Slavic languages and invariable appearance in negative constructions in the oldest written sources show that the genitive of negation should be reconstructed for at least the Proto-Slavic period, while the situation in Baltic languages is more complicated. In Lithuanian, the construction is firmly anchored in the written as well as spoken language. It has become obsolete in Latvian, but remnants in some of its dialects and more consistent appearances in older sources prove that it was once mandatory as well. While it can thus be reconstructed in the Eastern Baltic group, it is not necessary a selfevident Proto-Baltic feature, as it most likely did not exist in the Old Prussian of the Western Baltic branch according to the surviving monuments. A relatively small number of written sources, foreign influence and texts possibly written by non-native speakers make the question of Old Prussian genitive government especially challenging. 
The question of deeper historical connections between the Baltic and Slavic genitive of negation has been - as many other topics concerning the relationship between the two language groups - the subject of much discussion. Those who dispute the Balto-Slavic unity also suggest a parallel rather than genetic development of the syntactic rule. Senn $(1970,487)$, for example, argues that the genitive of negation is not limited to Baltic and Slavic, and is not consistent in either Russian or Lithuanian. Based on syntactic differences between the constructions in both language groups and a logical derivation from the partitive genitive, Kamp (2006) also assumes an independent (parallel) development.

Nevertheless, such argumentation is often based on (contemporary) optionality in Russian and far less convincing when considering a broader diachronic perspective that indicates a mandatory rule in the oldest sources of both language groups. Referring to examples outside the Balto-Slavic area, as explained earlier, cannot be considered a valid argument either. It is highly unlikely that such a specific, widespread phenomenon would arise in two neighboring language groups independently by chance alone with no other comparable constructions in other languages of the family. Much like other disputes regarding common Balto-Slavic development, often politically rather than scientifically motivated, we can dismiss these views. The question remains whether the genitive of negation can be traced back to the time of common Proto-Balto-Slavic or to a later stage in which mutual intelligibility and/ or general proximity between Proto-Slavic and (Eastern?) Proto-Baltic still enabled one to influence the other. Ancient Greek, Gothic, and Old High German evidence is a typological parallel (of isolated instances) at best, making a Proto-Indo-European origin of the construction implausible.

The partitive of negation in Finnish, on the other hand, cannot be left unnoticed, as it is an exact typological match to its Balto-Slavic genitive counterpart. Again, the geographical proximity of the languages and the syntactic distinctiveness of the construction make an independent parallel development questionable. Whether the construction (in either Balto-Finnic or Balto-Slavic) is indeed a calque, is difficult to say, as in this case, both groups are unrelated, and there are some major differences between the two categories (genitive vs. partitive case, genitive subjects in negated existential construction, etc.). Should we accept a cross-linguistic connection, BaltoSlavic is more likely to have influenced Balto-Finnic than the other way around. Specifically, many consider the Finnish partitive a Balto-Finnic innovation, making the Proto-Balto-Slavic construction most likely an older phenomenon.

Therefore, we can presume that the genitive of negation arose in Proto-BaltoSlavic or in a later time of intense linguistic contacts between Eastern Proto-Baltic and Proto-Slavic. Its likely genetic predecessor, the partitive genitive, on the other hand, is much older and was inherited from the Proto-Indo-European.

The partitive origins theory offers the most comprehensive explanation of the phenomenon. In accordance with the theory, the partitive genitive expanded to 
non-partitive complements in negative sentences, followed by the elimination of the partitive genitive and the emergence of the genitive vs. accusative contrast tied to negation exclusively. The transition from a lexical to a syntactic category, however, needs further elaboration. Besides, the genitive of negation also appears in languages which (have) retained the partitive genitive.

By including the concept of emphatic and reinforced negation, we can build a model with a plausible and comprehensive explanation of the genesis and subsequent development of the construction. Most of Timberlake's hierachies for Russian reflect a former partitive function, with emphatic negation seemingly another important factor in retaining genitive rection under negation. We assume that these characteristics can point to the origins of the construction and are either historical relics or typological parallels of the original role of the genitive objects under negation. The proposed model is summarized in Table 1.

Stage 1 marks the reconstructed Proto-Balto-Slavic case employment inherited from the Proto-Indo-European with the accusative as the most common complement of transitive verbs, regardless of negation. Already at this stage, however, some complements could also take the genitive case marking when the construction referred to (a part of) indeterminate, nonspecific quantity. The contrast was possible in both negative and affirmative sentences.

The turning point was the transition to Stage 2 when the partitive meaning of the genitive case in negative sentences became a marker of emphatic, pronounced negation. Sentences of the type nisem pil vode thus gradually shifted their meaning from 'I did not drink water (as such)' to 'I did not drink any water whatsoever'. A typological parallel can be found in Miklošič $(1883,500)$ : Czech tu sílu ${ }_{\text {acc. }}$ neměl 'he did not have the power' and sily ${ }_{\text {gen. }}$ nemél 'he did not have any power', analogous to German er hatte nicht die Kraft vs. er hatte keine Kraft.

Up to this point, direct objects could only appear in the genitive if they were able to carry a partitive meaning. This changed in Stage 3 when the genitive became the mandatory government of negated verbs - a result of the desire to reinforce negation. As pointed out earlier, there are several instances when the inherited Indo-European negative marker $n e$, which was often considered weak and a potential source of communication noise, was strengthened in various ways. This is why the genitive, originally an emphatic negation marker, became a neutral way of expressing negation and was now dependent on the negative marker as opposed to the verb. In this stage or earlier, the genitive spread to all complements, regardless of their potential partitive meaning, effectively forming an independent genitive of negation category. ${ }^{23}$ Most likely, the use of the partitive genitive, on the other hand, had already started declining at that point, thus increasing the contrast between affirmative and negative constructions.

${ }^{23}$ The same principle can be used to explain the genesis of the genitive of negation in existential sentences: $n i$ vode ${ }_{\text {gen. }}$ 'there is no water' should therefore historically be read as 'there is absolutely no water at all; none of this specific water nor any other water'. 
Table 1: Evolution of the genitive complements of transitive verbs

\begin{tabular}{|c|c|c|c|c|c|}
\hline & Stage 1 & Stage 2 & Stage 3 & Stage 4 & Stage 5 \\
\hline $\begin{array}{c}\text { Historical } \\
\text { period }\end{array}$ & $\begin{array}{l}\text { Proto-Indo- } \\
\text { European, } \\
\text { Proto-Balto-Slavic }\end{array}$ & $\begin{array}{l}\text { Proto-Balto- } \\
\text { Slavic? }\end{array}$ & $\begin{array}{l}\text { Proto-Balto- } \\
\text { Slavic or } \\
\text { Proto-Slavic } \\
\text { and (Eastern) } \\
\text { Proto-Baltic }\end{array}$ & $\begin{array}{l}\text { Individual } \\
\text { Baltic and } \\
\text { Slavic } \\
\text { languages }\end{array}$ & $\begin{array}{l}\text { (Some) Baltic } \\
\text { and Slavic } \\
\text { languages }\end{array}$ \\
\hline Description & $\begin{array}{l}\text { Opposition of } \\
\text { accusative and } \\
\text { partitive genitive } \\
\text { in both affirmative } \\
\text { and negative } \\
\text { sentences }\end{array}$ & $\begin{array}{l}\text { Opposition of } \\
\text { accusative and } \\
\text { partitive genitive } \\
\text { in both affirmative } \\
\text { and negative } \\
\text { sentences; through } \\
\text { its nonspecific, } \\
\text { all-inclusive } \\
\text { semantic value, } \\
\text { partitive genitive } \\
\text { in negative } \\
\text { sentences } \\
\text { develops emphatic } \\
\text { meaning }\end{array}$ & $\begin{array}{l}\text { Opposition } \\
\text { of accusative } \\
\text { and partitive } \\
\text { genitive in } \\
\text { affirmative } \\
\text { sentences; } \\
\text { genitive } \\
\text { becomes the } \\
\text { only possible } \\
\text { (neutral) } \\
\text { government } \\
\text { of transitive } \\
\text { verbs in } \\
\text { negative } \\
\text { sentences }\end{array}$ & $\begin{array}{l}\text { Opposition } \\
\text { of accusative } \\
\text { in affirmative } \\
\text { sentences } \\
\text { and genitive } \\
\text { in negative } \\
\text { sentences; } \\
\text { partitive } \\
\text { genitive is } \\
\text { gradu-ally lost }\end{array}$ & $\begin{array}{l}\text { By analogy, } \\
\text { accusative } \\
\text { replaces } \\
\text { genitive in } \\
\text { negative } \\
\text { sentences }\end{array}$ \\
\hline $\begin{array}{c}\text { Genitive } \\
\text { complement }\end{array}$ & $\begin{array}{l}\text { Complements that } \\
\text { can carry partitive } \\
\text { meaning }\end{array}$ & $\begin{array}{l}\text { Complements that } \\
\text { can carry partitive } \\
\text { meaning }\end{array}$ & $\begin{array}{l}\text { In this stage } \\
\text { or earlier, the } \\
\text { genitive case } \\
\text { spreads to } \\
\text { complements } \\
\text { that can not } \\
\text { carry partitive } \\
\text { meaning }\end{array}$ & $\begin{array}{l}\text { Any } \\
\text { complement }\end{array}$ & $\begin{array}{l}\text { Any } \\
\text { complement }\end{array}$ \\
\hline $\begin{array}{c}\text { Examples } \\
\text { (in Slove- } \\
\text { nian) }\end{array}$ & $\begin{array}{l}\text { Pil sem vodo } \\
\text { 'I was drinking (the) } \\
\text { water' (that specific } \\
\text { water in the jug) } \\
\\
\text { Pil sem vode } \\
\text { 'I was drinking (som. } \\
\text { water' (water as a } \\
\text { liquid, nonspecific, } \\
\text { indeterminate quantity) } \\
\\
\text { Nisem pil vodo } \\
\text { 'I was not drinking (the) } \\
\text { water' (that specific } \\
\text { water in the jug) } \\
\\
\text { Nisem pil vode } \\
\text { 'I was not drinking gen. } \\
\text { (any) water' (water as } \\
\text { a liquid, nonspecific, } \\
\text { indeterminate quantity) }\end{array}$ & $\begin{array}{l}\text { Pil sem vodo } \text { acc. } \\
\text { Pil sem vode } \\
\text { gen. } \\
\text { Nisem pil vodo } \\
\text { acc. } \\
\text { Nisem pil vode } \\
\text { (Any water at all, } \\
\text { neither the one in the } \\
\text { jug nor any other) }\end{array}$ & $\begin{array}{l}\text { Pil sem } \\
\text { vodo }_{\text {acc. }} \\
\text { Pil sem } \\
\text { vode }_{\text {gen. }} \\
\\
\text { Nisem pil } \\
\text { vode }_{\text {gen. }} \\
\text { (This water or any } \\
\text { water) }\end{array}$ & $\begin{array}{l}\text { Pil sem } \\
\text { vodo }_{\text {acc. }} \\
\text { Nisem pil } \\
\text { vode }_{\text {gen. }}\end{array}$ & $\begin{array}{l}\text { Pil sem } \\
\text { vodo } \\
\text { acc. } \\
\text { Nisem pil } \\
\text { vodo }_{\text {acc. }}\end{array}$ \\
\hline
\end{tabular}


Stage 3 can chronologically be placed in either the Proto-Balto-Slavic time or a later era of intense linguistic contacts between Proto-Slavic and Proto-Baltic (or alternatively, the period of the common ancestor of modern Lithuanian and Latvian if the absence of the construction in Old Prussian is an indicator that it had never used it, rather than lost it).

Starting with Stage 4, the genitive of negation has been relatively well documented in written sources. By the end of this stage, which has not yet been completed in all Baltic and Slavic languages, genitive complements in affirmative sentences are more or less eliminated, thus creating a clear-cut opposition of accusative rection in positive constructions and genitive rection in negative constructions. Such, for example, is the situation in modern Slovenian and Polish. Russian and Lithuanian, on the other hand, still retain the partitive genitive in affirmative sentences. Elsewhere, these forms are either archaic or lost.

Stage 5 is the final phase of the genitive of negation's development, ultimately resulting in its complete elimination due to syntactic leveling, with the accusative becoming the only possible government of transitive verbs in both affirmative as well as negative context. Most Baltic and Slavic languages, with the exception of Lithuanian and Polish, entered this stage at some point in the last 500 years. While some of them, such as Latvian and Czech, have reached its end, the extent of its completion varies in others. Last but not least, the boundaries between different stages might not always be clear-cut. There might especially be some overlap between Stage 4 and 5 , as evident in the case of Russian.

\section{Genitive complement of negated verbs in contemporary Slovenian}

The syntactic decline of the genitive of negation in Slovenian remains relatively unclear. The studies done so far generally agree that the long distance type is more susceptible to loss than the local one. Pronouns are also more likely to be replaced with accusative forms than nouns. Dual objects of negated transitive verbs (e.g., namestnica ni imela pravice ${ }_{\text {gen. }}$ dajati navodil ${ }_{\text {gen. }}$ 'the deputy did not have the right to give orders') can theoretically appear in four possible combinations: genitive/genitive, genitive/accusative, accusative/accusative, and accusative/genitive. According to Ilc (2009), the latter is far less frequent than the first three.

Several empirical analyses of the construction's use in contemporary Slovenian have been carried out, most of them analyzing text corpora (e.g., from the media) or using questionnaires to survey native speakers. People taking part in such studies are usually asked to identify and correct grammatical mistakes in a given text, which include many instances of direct objects in the accusative under negation. Typically, the genitive-accusative focus of the research is not revealed to the participants until the end of the survey, so as not to influence their answers.

One of such studies was done by Božič, Komac, Tomažin, and Verovnik (1998, 9-10), who found out that most respondents did not master the accusative-genitive 
opposition in affirmative and negative sentences. In the questionnaire, in which the respondents had to find and fix any grammatical mistakes, $74.6 \%$ of incorrectly used accusative complements in negative constructions were corrected. Negative and nonspecific indefinite pronouns were the most frequent among the undetected mistakes. Proper names, on the other hand, had the highest rectification rate.

The main problem of such surveys - in addition to relatively small samples - is their focus on testing the (acquired) knowledge of the standard language rather than the actual use in the spoken language. The participants are under the pressure of being perceived as sloppy, uneducated speakers, should they not identify the mistakes in the text. Moreover, they might identify the true purpose of the survey and then consciously look for and correct all accusative objects.

\subsection{Methodological outline}

The main purpose of our research was to analyze and describe the declining usage of the genitive of negation in contemporary spoken Slovenian, with the emphasis on the aspects that could shed light on the question of its genesis.

To avoid the limitations and methodological shortcomings of previous studies, we focused on analyzing the linguistic perception of the speakers. The respondents were not asked to correct mistakes or evaluate their own use/knowledge of the genitive of negation, but to assess the general use of genitive complements that they observed in their daily communication with other speakers. The respondents were asked to evaluate how acceptable the given examples would be in informal linguistic situations, i.e., how often they taught their interlocutors would use them in conversation. This was done in order to reduce the sense of respondents that we were evaluating their linguistic skills, and consequently, to avoid the possibility of having them reply in a way they would think they needed to reply and not so that their answers would reflect linguistic reality as genuinely as possible.

Another fail-safe mechanism in the survey was using only accusative, i.e., incorrect forms of complements. That made all examples in the questionnaire stylistically equal and corresponding variables more robust, since in a survey combining accusative and genitive forms respondents could favor the latter over the former due to their normality, giving them higher perceived frequency estimates when evaluating their frequency in spoken language.

When generating the grading scale, we renamed "frequency" to "acceptability" to enable easier and faster assessment. A Likert scale of five ordered response levels was used (" 1 " meaning very uncommon and " 5 " very common) in order to transform the answers into an interval level of measurement, thus making it possible to compare evaluations of the accusative frequency in different syntactic settings.

Each participant was asked to provide his/her basic dialect group, highest level of education attained, potential linguistic education/training, and birth year. Although we did not ask the respondents to only evaluate linguistic situations among the speakers of their own dialect, level of education or age group, we assumed that each of 
them would automatically, subconsciously or consciously, evaluate the given examples through his/her internal linguistic system, use his/her own sense of the language and thus more or less reflect the characteristics of his/her demographic group. The survey itself was anonymous.

Our goal was to first analyze three basic grammatical categories and their correlation with the genitive of negation. Based on Timberlake's concept of hierarchies, we chose three specific binary categories to find syntactic or semantic elements that could confirm the partitive-emphatic origins of the construction. As the partitive genitive is most often used to refer to a part of inanimate and mass, as opposed to count reality, we chose these three categories:

- Countability (count vs. mass complements),

- Animacy (animate vs. inanimate complements),

- Emphasis (emphatic vs. neutral negation).

Each category was tested through pairs of sentences, with the two sentences only differing in the given category while keeping as many other grammatical features as possible the same in both sentences. ${ }^{24}$ For example, the pair: Še vedno ne morem premakniti ta kamen ${ }_{\text {acc. }}$ 'I still cannot move this rock' and Še vedno ji noče kupiti

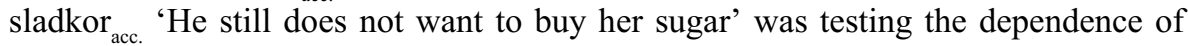
the genitive of negation's retention on countability of the complement. The object in the first sentence is a count noun and the one in the second sentence a mass noun. At the same time, both are masculine complements in the singular, part of an infinitive construction preceded by a modal verb.

Eight sentence pairs were used for each category, with the pairs differing from one another in many grammatical features to neutralize possible impact of additional factors. We compared the average grades for both sentences in each pair to see whether the difference was statistically significant and whether it was likely that the occurrence of the accusative was more frequent in one sentence than the other also at the population.

In addition to the three basic categories, we defined several second level categories, as we also wanted to analyze potential impact of other variables. Again, we included some of Timberlake's findings in Russian and tested whether there is a causal relationship in contemporary Slovenian between gender, number, distance, aspect, or mood on the one hand, and the preservation of the genitive of negation on the other hand. When putting the sentences together, caution was taken to make sure that the share of masculine and feminine, as well as singular and plural complements was approximately the same. The percentage shares of neuter nouns and nouns in the dual

${ }^{24}$ The names of dependent variables, i.e., numerical assessments of acceptability/frequency of the accusative case in a given sentence, consisted of three elements. The first three letters refer to the category under examination (cnt for countability, emp for emphasis, and ani for animacy.), followed by the sequential number of the sentence pair. The variable name concludes with label $a$ for the first sentence and label $b$ for the second sentence in a pair (cnt1 $a$ and cnt $1 b$, cnt $2 a$ and $c n t 2 b$, etc.). 
were somewhat smaller. ${ }^{25}$ A majority of the sentence pairs had a local object, there were, however, some with a long distance object. Approximately half of all verbs used were perfective, and half of them were imperfective. Most of the sentences were written in the indicative mood with some using the conditional or imperative mood. Sentences in a given pair were always identical in all the first and second level categories, with the exception of one of the three first level categories, subject to examination.

Complements in all $48(=3 \times 8 \times 2)$ sentences were nouns (mostly without an attribute). Therefore, four sentences with pronominal objects nič, to, jo, tele were added to the original list.

In order to test the second level categories, 15 indices were introduced (masculine, feminine, neuter, singular, dual, plural, local, distant, perf, imperf, indicat, conditnl, imper, noun, and pronoun), as well as four additional indices tracking sentences with selected combinations of gender and number (mascsg, femisg, mascpl, and femipl). These composite statistics were a compound measure calculated by adding evaluations of all sentences that met the given grammatical criteria and dividing them by the number of sentences, for each respondent. They represent an average numerical estimate of accusative frequency in all sentences whose elements match the given category. The index singular, for example, tells us how, on average, a respondent graded the accusative acceptability degree in all negative sentences with a singular complement.

The sentence selection was constrained by certain grammatical forms with ambiguous morphological interpretations. It was thus not possible to examine the distribution of the accusative/genitive for complements that were animate nouns of the first masculine declension in the singular, where both cases are identical. A similar ambiguity appears with the accusative plural form of the first and second feminine declension that are identical to the corresponding genitive singular forms (as well as the genitive plural in the case of the second declension). This was solved by adding context to clarify the intended number and case. ${ }^{26}$

\subsection{Data sample}

For easier data collection and to reach more people, an electronic survey was posted in social media, as well as sent out by email to students and teachers, asking them to fill out and further disseminate the questionnaire. The poll that was open for 16 days received 525 responses. Almost a quarter of the respondents (23.4\%) did not finish the survey, probably mostly due to its length.

The data sample included speakers from all dialect groups. The majority of the respondents identified themselves as speakers of Ljubljana/Central Slovenian

${ }^{25}$ Not to diminish the role of the neuter gender or dual but to more closely reflect the distribution in the language, in which these two categories are relatively less frequent compared to their categorical counterparts.

${ }^{26}$ For example, Sodelavke ne tikaj 'Do not address (a) (female) coworker(s) informally with 'ti", which can either mean $a$ coworker in the genitive or (all) coworkers in the accusative, was replaced by Sodelavke ne tikaj, če ti tako ne predlagajo same 'Do not address (female) coworkers informally with 'ti' unless they suggest that themselves'. 
varieties (53.5\% of those who answered the question). They were followed by speakers from Styrian (10.4\%), Littoral (10.2\%), Lower Carniolan (9.0\%), Upper Carniolan $(6.2 \%)$, Pannonian (5.2\%), Rovte (1.7\%), and Carinthian (1.0\%) dialect group. Two percent of the respondents did not identify their Slovenian dialect with any of the given groups, while $1.7 \%$ of them were not native speakers of Slovenian.

The highest percentage share of the respondents ( $47.0 \%$ of all valid values) had undergraduate university degree, while a quarter of them had attained gymnasium (high school) education (25.2\%). They were followed by those who had completed graduate programs (13.8\%), vocational high schools (6.5\%), higher vocational education $(5.0 \%)$, and elementary school or less $(1.2 \%)$. More than a quarter (27.2\% of all valid values) of the participants had studied Slovenian, foreign languages, or linguistics. On the other hand, $72.8 \%$ had not had any specialized linguistic education and/or training prior to the survey.

The majority of the respondents were between 20 and 35 years old, although there were several younger and older speakers sampled as well (the youngest was 15, and the oldest was 76 years old). The average age of the respondents was 30.5 years with the age distribution asymmetrically stretched to the right. The respondents were placed into five age groups; the most numerous group included respondents between the age of 25 and 35 years ( $54.1 \%$ of all valid values), followed by those younger than $25(25.1 \%)$, between 35 and 45 years $(9.0 \%), 45$ and 55 years $(7.3 \%)$, and those aged 55 years or more $(4.5 \%)$. The ranges of the group were set so each group included its lower and excluded its upper age limit.

The interpretation of the survey's results needs to take the particularities of the sample into consideration. There was an above average percentage of participants who spoke Ljubljana and/or Central Slovenian varieties, those with undergraduate and graduate education, those who had studied linguistic topics after high school, and respondents aged between 20 and 35 years. The results from the sample thus might not perfectly reflect the general situation at the population level, but are more representative of people belonging to abovementioned demographic groups.

Due to the lack of tangible and reliable data for some of the demographic indicators at the population level (e.g., the number of speakers in individual dialect groups or the percentage share of people with any form of linguistic education), as well as the fact that some demographic groups in the sample were too small, no weights were used. Every statistical analysis, however, was calculated for the entire sample and on a group-by-group basis.

\subsection{Results}

A composite variable meanval was first computed for each respondent, as an arithmetic mean of all his/her evaluations of accusative acceptability for all the given sentences. The mean value of the variable for the entire sample was 2.84 (standard deviation $s=0.85),{ }^{27}$ indicating that, on average, the respondents perceived accusa-

${ }^{27}$ In the following analysis, $N$ refers to the number of valid values for a given variable, while the number of missing values is evident from the difference between the number of units in the sample (525) and $N$. Furthermore, $\bar{x}$ refers to the sample mean and $s$ to the standard deviation of a given variable. In determining statistical significance in the analysis, information is provided on 
tive complements in negative sentences as relatively common/acceptable in spoken language. Table 2 shows that the accusative is most frequent in the following sentences: Ni ji prinesel nič, čeprav je imela rojstni dan (average grade $\overline{\mathrm{X}}=4.02$ ); $\mathrm{Ne}$ pozabi kupiti kremo, za katero sem te prosila (3.90); To si ne bom dovolil (3.83); $\mathrm{Ni}$ sta jo videla, ker so se ravno zgrešili (3.73), and Ne pozabi pozdraviti sosedo (3.72).

Table 2: Sentences with the highest average accusative acceptability estimates

\begin{tabular}{|c|c|c|}
\hline Sentence & Translation & $\bar{x}$ \\
\hline $\begin{array}{l}\text { Ni ji prinesel nič }{ }_{\text {acc.sg. }} \text { čeprav je imela } \\
\text { rojstni dan. }\end{array}$ & $\begin{array}{l}\text { He did not bring her anything, even though } \\
\text { it was her birthday. }\end{array}$ & 4.02 \\
\hline $\begin{array}{l}\text { Ne pozabi kupiti kremo }{ }_{\text {acc.sg.f. }} \text {, za katero sem } \\
\text { te prosila. }\end{array}$ & $\begin{array}{l}\text { Do not forget to buy the lotion for which I } \\
\text { asked you. }\end{array}$ & 3.90 \\
\hline To $o_{\text {acc.sg.n. }}$ si ne bom dovolil. & I will not allow this. & 3.83 \\
\hline Nista jo $_{\text {acc.sg.f. }}$ videla, ker so se ravno zgrešili. & $\begin{array}{l}\text { The two of them did not see her because } \\
\text { they just missed each other. }\end{array}$ & 3.73 \\
\hline Ne pozabi pozdraviti sosedo ${ }_{\text {acc.s.f. }}$ & Do not forget to greet the neighbor. & 3.72 \\
\hline $\begin{array}{l}\text { Tista dva stola } \\
\text { razprodaji, če sta bila tako draga. }\end{array}$ & $\begin{array}{l}\text { He has obviously not gotten those two } \\
\text { chairs on sale if they were that expensive. }\end{array}$ & 3.59 \\
\hline $\begin{array}{l}\text { Če ne bi puščali svoje zvezke } \\
\text { vsepovsl.m. } \\
\text { sod, bi lahko hitreje pospravili. }\end{array}$ & $\begin{array}{l}\text { If you did not leave your notebooks } \\
\text { everywhere, you could clean up faster. }\end{array}$ & 3.46 \\
\hline Ob nedeljah ni nikoli kosil travo ${ }_{\text {acc.sg.f }}$ & On Sundays, he never mowed the lawn. & 3.45 \\
\hline $\begin{array}{l}\text { To številko }{ }_{\text {acc.sg.f. }} \text { ponavadi ne uporablja, ker } \\
\text { ima še en mobitel. }\end{array}$ & $\begin{array}{l}\mathrm{He} / \mathrm{she} \text { usually does not use that number, } \\
\text { because he/she has another cell phone. }\end{array}$ & 3.40 \\
\hline $\begin{array}{l}\text { Iščeš čevlje? Zakaj pa ne nosiš tele acc.pl.m? } \\
\text { Lepši so od vseh drugih. }\end{array}$ & $\begin{array}{l}\text { Are you looking for (your) shoes? Why are } \\
\text { you not wearing these? They are nicer than } \\
\text { all the rest. }\end{array}$ & 3.36 \\
\hline
\end{tabular}

Three of the five sentences with the highest average estimate of the accusative occurrence used a negative, demonstrative, or personal pronoun as the complement, and two used a long distance object with an infinitive construction. This endorses the findings of other surveys that showed the genitive of negation was more likely to be replaced when the object was a pronominal complement, especially the pronoun nič (cf. Božič et al., 1998). The same holds true of the long distance genitive of negation.

The respondents were least likely to hear an accusative form in sentences Nista mi dala prav nobene žeblje, temveč samo vijake $(\overline{\mathrm{x}}=1.93)$; Nobene znance ne srečamo več (2.00); Anja pač ne mara USB ključek (2.05); Ne pošiljajo mi več nobene kataloge

the value of $t$ or $F$ according to the types of variables for which the correlation is observed. Also provided is the number of degrees of freedom $(d f)$ and level of significance (sig.). In the survey, correlation between two variables is treated as statistically significant if the level of significance (probability of rejecting the null hypothesis given that it is true) is lower than $5 \%(\mathrm{sig} .<0.050)$. 
(2.17); and Ob sredah v šolo ni nosila torbo (2.20) (see Table 3). It is worth mentioning that four out of these five sentences have a masculine complement, and at the same time, three of them contain emphatic negation with (prav) noben 'none at all'.

Respondents' answers varied most when they were evaluating the acceptabil-

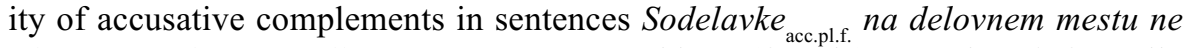
tikaj, če ti tako ne predlagajo same 'Do not address (female) coworkers informally with 'ti' unless they suggest that themselves' $(s=1.48)$; Ni pozabila dvojčici ${ }_{\text {acc.du.f.' }}$ $s$ katerima je preživela otroštvo 'She did not forget the (female) twins with whom

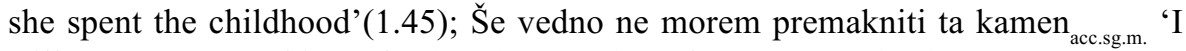
still cannot move this rock' (1.44); Sosedova fanta ${ }_{\text {acc.du.m. }}$ od takrat naprej ni več maral 'He did not like the neighbor's (two) boys since then' (1.44); and Prosim, ne puščaj denarnico ${ }_{\text {acc.sg.f. }}$ na sedežu 'Please, do not leave the valet in the seat' (1.43). The respondents were most united regarding the occurrence of the accusative in sentences Nista mi dala prav nobene žeblje, temveč samo vijake (1.15); Ni ji prinesel nič, čeprav je imela rojstni dan (1.16); Nobene znance ne srečamo več (1.18); Ne odpiraj nobeno steklenico (1.21); and Ne pozabi kupiti kremo (1.24) (see Table 2 and 4 for translations).

Table 3: Sentences with the lowest average accusative acceptability estimates

\begin{tabular}{|c|c|c|}
\hline Sentence & Translation & $\bar{x}$ \\
\hline $\begin{array}{l}\text { Nista mi dala prav nobene žeblje }{ }_{\text {acc.pl.m.' }} \\
\text { temveč samo vijake! }\end{array}$ & $\begin{array}{l}\text { 'The two of them have not given me any } \\
\text { nails at all, just screws! }\end{array}$ & 1.93 \\
\hline $\begin{array}{l}\text { Vsi so se preselili. Nobene znance } \text { acc.pl.m. } \text { ne } \\
\text { srečamo več. }\end{array}$ & $\begin{array}{l}\text { 'They have all moved. We do not meet any } \\
\text { acquaintances (whatsoever) anymore. }\end{array}$ & 2.00 \\
\hline $\begin{array}{l}\text { Anja pač ne mara USB ključe } k_{\text {acc.sg.m. }} . \check{S} e \\
\text { vedno uporablja diskete. }\end{array}$ & $\begin{array}{l}\text { Anja simply does not like the USB drive. } \\
\text { She still uses floppy disks. }\end{array}$ & 2.05 \\
\hline $\begin{array}{l}\text { Odkar je izšla nova kolekcija, mi ne } \\
\text { pošiljajo več nobene kataloge }{ }_{\text {acc.pl.m. }}\end{array}$ & $\begin{array}{l}\text { Ever since the new collection came out, they } \\
\text { have not been sending me any catalogues } \\
\text { (whatsoever) anymore. }\end{array}$ & 2.17 \\
\hline Ob sredah v šolo ni nosila torbo $o_{\text {acc.sg.f }}$ & $\begin{array}{l}\text { On Wednesdays, she did not carry the bag } \\
\text { to school. }\end{array}$ & 2.20 \\
\hline Ne odpiraj nobeno steklenico acc.sg.f. $^{!}$ & Do not open any bottle (at all)! & 2.21 \\
\hline Nikoli še ni videl prave volkove ${ }_{\text {acc.pl.m. }}$ & He has never seen real wolves. & 2.22 \\
\hline $\begin{array}{l}\text { Glede sestanka ne potrebujem njegove } \\
\text { papirje } \text { acc.pl.m. } \text { ker je v njih preveč napak. }\end{array}$ & $\begin{array}{l}\text { As far as the meeting is concerned, I do not } \\
\text { need his papers as they contain too many } \\
\text { mistakes. }\end{array}$ & 2.25 \\
\hline $\begin{array}{l}\text { Jaz si ne bi kupila noben nakit }{ }_{\text {acc.sg.m. }} \text {, če mi } \\
\text { ne bi ti tako predlagala! }\end{array}$ & $\begin{array}{l}\text { I would not have bought any jewelry } \\
\text { (whatsoever) if you had not suggested } \\
\text { otherwise! }\end{array}$ & 2.37 \\
\hline Pač ne prenaša hrup acc.sg.m. Ni edina. & $\begin{array}{l}\text { She simply does not tolerate noise. She is } \\
\text { not the only one. }\end{array}$ & 2.38 \\
\hline
\end{tabular}




\subsubsection{Correlation between perceived accusative acceptability and demographic variables}

The perceived degree of acceptability/frequency of the accusative case in negative sentences was most affected by the dialect group of the respondent. In 16 out of 52 sentences the differences between dialect groups were statistically significant. Figure 1 shows average estimates for the respective sentences across different dialect groups. Each colored line represents one sentence.

The chart points out some characteristic differences between dialect groups. The top three lines, representing average grades for sentences $p r 2, p r 1$, and cnt $3 a$, stand out with significantly higher perceived accusative frequencies than other sentences. Two of them have a pronominal complement, and the third one is Mar spet nisi poklicala teto ${ }_{\text {acc.sg.f. }} i z$ Novega mesta 'Have you not called the aunt from Novo mesto again?'. These three sentences, especially in the Upper Carniolan group, do not follow the general trend, i.e., generally lower acceptability estimates than in other dialect groups. The distinct peaks in the Lower Carniolan and Pannonian group for the majority of sentences, as well as a subtle trough in the Styrian group, indicate a more frequent detection of accusative complements in the former two and less frequent detection in the latter group.

Figure 1: Statistically significant differences between dialect groups - average grade comparison (See webpage of SJ/SLS for color version of this graph)

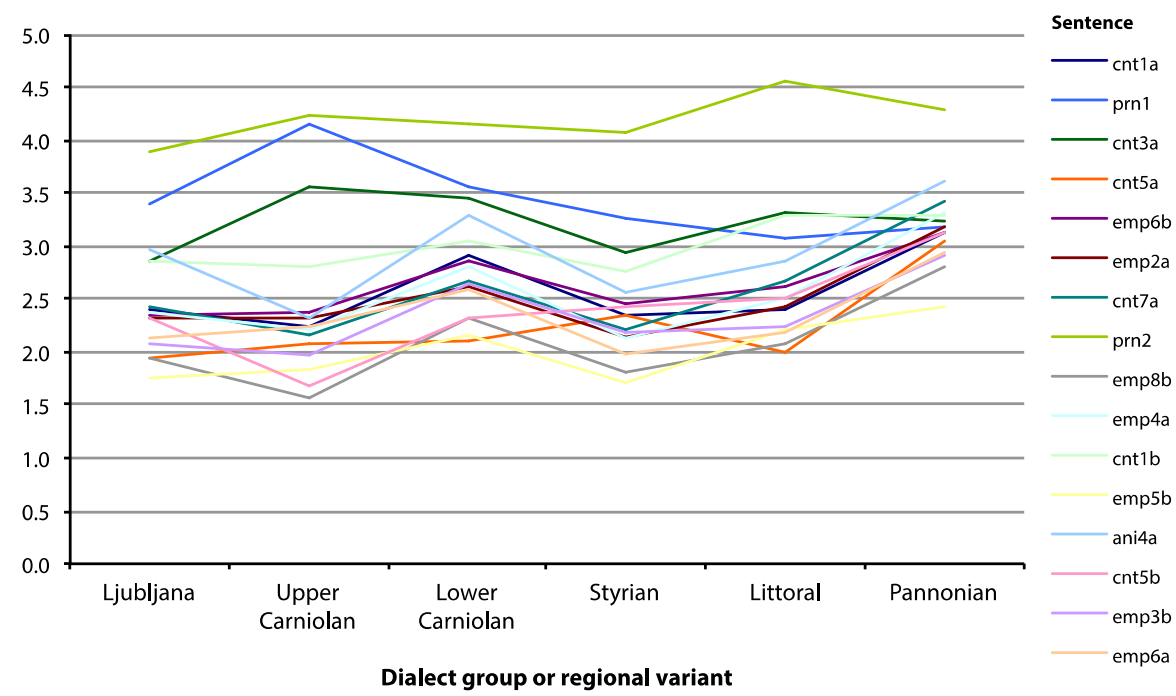

The correlations between the perceived accusative occurrence on the one hand, and linguistic education/training, age group, and education level of the respondent on the other hand are somewhat weaker. There are eight sentences with statistically 
significant grade differences between linguists ${ }^{28}$ and non-linguists, as opposed to seven between respondents of different age groups, and six between respondents of different education levels.

There are only few general tendencies that can be inferred regarding the differences between respondents of various levels of education. Participants with undergraduate education assigned higher estimates and seem to have perceived the accusative instead of the genitive in the given sentences more often than their graduate colleagues or those who completed a higher vocational program. Other levels of education do not seem to follow identifiable common tendencies in the sentences that show significantly different grades between education profiles. Unlike the difference between linguists and non-linguists, where the former perceived accusative forms in selected negative sentences much more frequently than their peers. A somewhat surprising result can most likely be explained by the fact that linguists are often more susceptible to grammatical errors and notice them more frequently than non-linguists.

Age groups do not seem to follow a distinctive pattern either. The only noteworthy observation in Figure 2 is a trough in the age group of 45-55 years and a peak at the group consisting of respondents aged 55 years and older. Respondents in the first group observed accusative complements in their day-to-day communication relatively less frequently, while those in the oldest age group seem to have found the given accusative forms much more acceptable in their linguistic environment.

Figure 2: Statistically significant differences between age groups - average grade comparison (See webpage of SJ/SLS for color version of this graph)

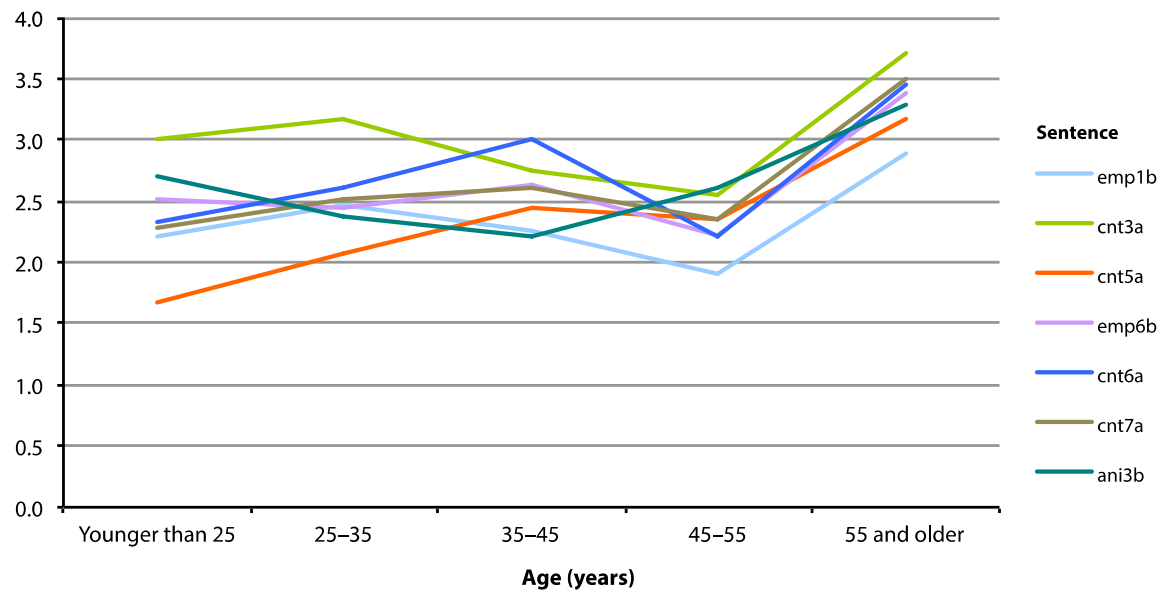

${ }^{28}$ For the purpose of the research, linguists were defined as respondents who had any higher academic or professional education/training in Slovenian, foreign languages, or linguistics in general. 
It is worth noting that the abovementioned observations and statistically significant differences only hold for a small number of sentences. With the exception of dialect groups, respondents with diverse demographic traits do not seem to differ much in how often they hear or deem acceptable an accusative form in a certain sentence. A more reliable indicator of correlation is the meanval index that combines grades for all the sentences that a respondent evaluated (which equals 52 sentences for more than three quarters of participants). This arithmetic mean, which can predict general accusative use under negation and/or perception thereof much better than individual grades, statistically only differs between dialect groups, in accordance with our earlier observations $(F=2.20, d f=9$, sig. $=0,021)$.

Figure 3: Variable meanval across dialect groups - mean values

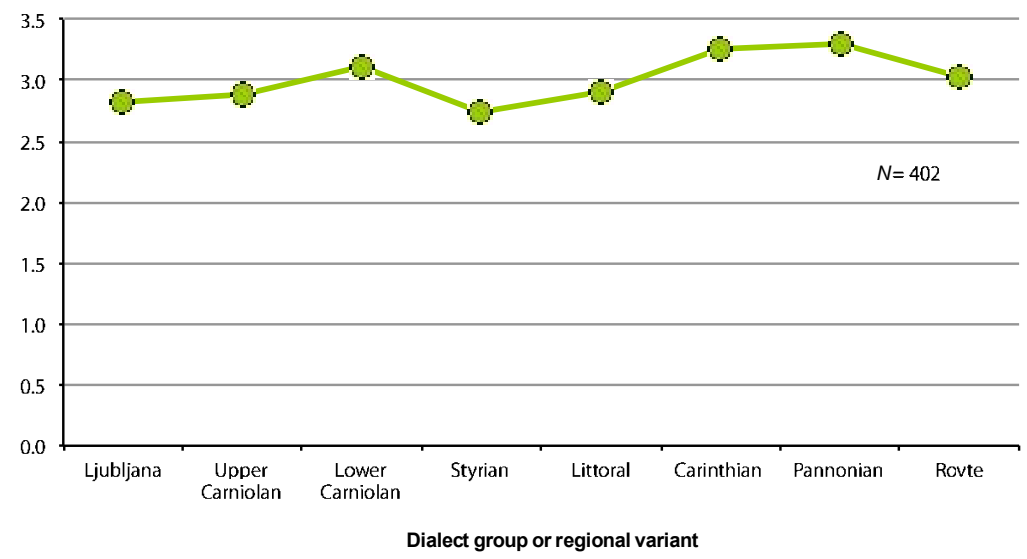

Figure 3 illustrates the differences in average meanval values between dialect groups. Speakers of Styrian dialects $(\bar{X}=2.73)$ and Central Slovenian varieties (2.82) seem to observe the decline of the genitive of negation in negative sentences least often as they find accusative complements least common. They are closely followed by Upper Carniolan (2.89), Littoral (2.90), and Rovte (3.04) dialect groups. Accusative instead of genitive seems to be most prevalent among Pannonian (3.31), Carinthian (3.26), and Lower Carniolan (3.11) speakers. ${ }^{29}$

\subsubsection{Level one categories - countability, animacy, and emphatic negation}

All three primary categories were tested across eight pairs of sentences, each of which differed in the given category while having identical values of as many other

${ }^{29}$ The possibilities of generalizing these findings at the population level are limited in the case of Carinthian and Rovte dialect group due to a low number of respondents that identified themselves as their speakers. 
grammatical parameters as possible. The sentence pairs were analyzed in two ways. First, we compared the average grades of perceived accusative acceptability for both sentences in each pair. We then compared the average values of the composite variables defined as arithmetic means of eight sentences - one from each pair — that had the same value of the primary category.

When testing the impact of countability, for example, we first compared mean values of cnt $1 a$ with mean value of $c n t 1 b$, then $c n t 2 a$ with $c n t 2 b$, etc. The first sentence in each of these eight pairs contained a complement that was a count noun, while the complement in the second sentence was a mass noun. We used the $t$-test to determine whether the two sets of data were significantly different from each other, which would mean that the perceived accusative acceptability in the two sentences differs in the general population as well. Finally, we introduced indices count (and uncount, the first one calculated as the arithmetic mean of the grades assigned to all eight sentences with count complements, and the second one as the arithmetic mean of the other eight sentences with mass complements.

Table 4 sums up the primary analysis, listing mean values of accusative acceptability for both sentences $\left(\overline{\mathrm{X}}_{1}\right.$ and $\left.\overline{\mathrm{X}}_{2}\right)$ in each pair of all three categories, as well as significance (alpha level), i.e., probability that the difference between the two means was due to chance alone. Shaded cells represent mean values of sentences that had significantly higher average perceived accusative frequencies than their partner sentences with the opposite primary category value.

Five out of eight sentences in the countability category indicate significantly different genitive replacement frequency; the same is true for six sentences in the animacy category. Furthermore, all eight sentences in the emphatic negation category show statistically significant differences, even at a more stringent $\boldsymbol{\alpha}=0.01$ level. Mean values of all three composite variable pairs are significantly different within the pair (count vs. uncount: $t=-7.44 ; d f=442 ;$ sig. $=0.000$; anim vs. inanim: $t=-5.75$; $d f=521 ;$ sig. $=0.000$; and emph vs. neutr: $t=-11.90 ; d f=522 ;$ sig. $=0.000)$.

Table 4: Differences between mean values in the category of countability, emphasis, and animacy

\begin{tabular}{|c|c|c|c|c|c|c|c|c|c|c|c|}
\hline Countability & $\bar{X}_{1}$ & $\bar{x}_{2}$ & sig. & Animacy & $\overline{\mathrm{X}}_{1}$ & $\bar{x}_{2}$ & sig. & Emphasis & $\overline{\mathrm{X}}_{1}$ & $\bar{x}_{2}$ & sig. \\
\hline cnt1a : cnt1b & 2.45 & 2.96 & $0.000^{*}$ & ani1a : ani1b & 3.72 & 3.90 & 0.229 & emp1a : emp1b & 2.55 & 2.37 & $0.001 *$ \\
\hline cnt2a : cnt2b & 2.20 & 3.45 & $0.000^{*}$ & ani2a : ani2b & 3.12 & 3.40 & $0.000^{*}$ & emp2a : emp2b & 2.41 & 2.67 & $0.000^{*}$ \\
\hline cnt3a : cnt3b & 3.05 & 3.10 & 0.802 & ani3a : ani3b & 3.18 & 2.50 & $0.000^{*}$ & emp3a : emp3b & 3.19 & 2.21 & $0.000^{*}$ \\
\hline cnt4a: cnt4b & 3.26 & 3.13 & $0.028^{*}$ & ani4a : ani4b & 2.97 & 2.69 & $0.005^{*}$ & emp4a : emp4b & 2.44 & 2.99 & $0.000^{*}$ \\
\hline cnt5a : cnt5b & 2.05 & 2.38 & $0.000^{*}$ & ani5a : ani5b & 2.76 & 3.59 & $0.000^{*}$ & emp5a : emp5b & 2.66 & 1.93 & $0.000^{*}$ \\
\hline cnt6a : cnt6b & 2.57 & 2.78 & $0.006^{*}$ & ani6a : ani6b & 2.22 & 2.95 & $0.000^{*}$ & emp6a : emp6b & 2.25 & 2.50 & $0.000^{*}$ \\
\hline cnt7a : cnt7b & 2.51 & 2.60 & 0.172 & ani7a : ani7b & 3.02 & 3.46 & $0.000^{*}$ & emp7a : emp7b & 2.91 & 2.17 & $0.000^{*}$ \\
\hline cnt8a : cnt8b & 2.95 & 2.81 & 0.158 & ani8a : ani8b & 3.23 & 3.31 & 0.098 & emp8a : emp8b & 3.21 & 2.00 & $0.000^{*}$ \\
\hline count : uncount & 2.60 & 2.87 & $0.000^{*}$ & anim : inanim & 3.05 & 3.22 & $0.000^{*}$ & neutr : emph & 2.68 & 2.37 & $0.000^{*}$ \\
\hline
\end{tabular}

* Level of significance lower than $5 \%$ 
The results imply that all three categories could possibly affect the likelihood of replacing the genitive of negation with the accusative. Mass nouns used as objects of negated direct verbs thus seem to be more likely to appear in the accusative than count nouns. The same holds true for inanimate complements. Nonetheless, it needs to be emphasized that both the first and the second hypothesis are only supported by four out of eight testing sentence pairs (with one and two additional pairs, respectively, implying the opposite in each category). Emphasis, on the other hand, suggests a stronger correlation, as all eight sentence pairs in the category have significantly different estimates. Emphatic negation seems to preserve genitive complements much better than neutral negation (there are, however, three sentences that imply the opposite).

Using only a few sentences to test each category is a considerable, yet inevitable statistical limitation. In spite of comprising only 52 sentences, the survey had a $23.4 \%$ dropout rate with some negative comments on the excessive length of the questionnaire. Additional sentences could considerably decrease the number of respondents and completed entries. Also, creating a set of sentences with all possible combinations of numerous grammatical categories would make such a survey unreasonably long.

By omitting the ceteris paribus requirement, however, an additional insight into the relationship between the three categories and the genitive of negation can be obtained. Six supplementary indices were calculated, this time comprising accusative acceptability evaluations in all complements matching the given category, not just the selected eight. In fact, this substantially affects the results: the difference between sentences with count $(\bar{X}=2.77)$ and mass $(2.75)$ objects no longer seems significant $(t$ $=0.846 ; d f=522$; sig. $=0.398)$. The impact of animacy on the retention of the genitive of negation still seems possible, as the difference between animate $(\bar{X}=2.95)$ and inanimate complements (2.71) is statistically significant for the chosen sentences $(t=$ 9.997; $d f=524$; sig. $=0.000)$. This time, however, the influence seems reverse, with animate complements more likely to appear in the accusative than inanimate ones. Emphatic negation, on the other hand, not only retains its low statistical significance $(t=19.930 ; d f=522$; sig. $=0.000)$, but also records a greater difference between sentences with neutral (2.85) and emphatic (2.37) negation.

Based on these findings, we cannot confirm a correlation between countability (or animacy) of the complement and the likelihood of Slovenian speakers employing the accusative instead of the genitive under negation. The abovementioned volatility of statistical results for the two categories, caused by a relatively small number of sentences tested and the fact that it is difficult to cover all relevant syntactic environments in a survey, makes it likely to conclude there is no dependence between these categories. The impact of emphatic negation, on the other hand, appears to be much more robust and has a high significance when testing either through the ceteris paribus model or in all sentences. This implies that when using emphatic negation, Slovenian speakers are more likely to preserve the genitive of negation. Also, five out of ten sentences with the lowest average grade of perceived accusative frequency contained emphatic negation. 
This proves that the historical emphatic markedness of genitive objects in negative constructions is still reflected at a syntactic level today in spite of its historical neutralization in the process of establishing the genitive of negation. While we have shown that the genitive of negation is better preserved in sentences with emphatic negation in Slovenian, similar observations can be found in the literature about Russian, Serbian and Croatian, and until recently, Czech and Slovak. Obviously, this might not necessarily be an inherited syntactic feature, but possibly a cognitive sense of (subconsciously) relating emphatic negation to the genitive.

\subsubsection{Level two categories - number, gender, aspect, mood, distance, noun/pro- noun}

Composite statistics measuring the effect of the level two categories were calculated as mean values of all variables referring to a sentence that matched the given category. Since these indices were thus based on a larger number of sentences compared to the level one categories, they can be deemed more reliable. They do not however isolate the effect of an individual grammatical category the way the three sets of eight sentence pairs did within level one categories. Out of 18 variable pairs in Table 5, 17 show significant differences in mean values of each variable pair.

In terms of grammatical number, the differences between the average perceived accusative frequencies are greatest between dual $\left(\overline{\mathrm{X}}_{1}=3.00\right)$ and plural $\left(\overline{\mathrm{X}}_{2}=2.76\right.$; $t=7.28 ; d f=443 ;$ sig. $=0.000)$, followed by singular $\left(\overline{\mathrm{X}}_{1}=2.87\right)$ and plural $(t=4.94$; $d f=523$; sig. $=0.000)$. The difference between singular and dual is smaller, but still significant $(t=-2.18 ; d f=443 ;$ sig. $=0.029)$. The accusative appears to replace the genitive most frequently when the complement is in the dual, followed by complements in the singular and in the plural. In spite of statistical significance, the differences tend to be minor.

Table 5: Differences in means of secondary derived variables

\begin{tabular}{|l|c|c|c|l|c|c|c|}
\hline Variable pair & $\overline{\mathrm{X}}_{1}$ & $\overline{\mathrm{X}}_{2}$ & sig. & Variable pair & $\overline{\mathrm{X}}_{1}$ & $\overline{\mathrm{X}}_{2}$ & sig. \\
\hline singular : dual & 2.87 & 3.00 & $0.029^{*}$ & conditnl : imper & 2.87 & 3.27 & $0.000^{*}$ \\
\hline singular : plural & 2.87 & 2.76 & $0.000^{*}$ & local : distant & 2.82 & 3.15 & $0.000^{*}$ \\
\hdashline dual : plural & 3.00 & 2.76 & $0.000^{*}$ & noun : pronoun & 2.79 & 3.65 & $0.000^{*}$ \\
\hdashline masculine : feminine & 2.61 & 3.06 & $0.000^{*}$ & mascsg : femisg & 2.47 & 3.07 & $0.000^{*}$ \\
\hdashline masculine : neuter & 2.61 & 2.88 & $0.000^{*}$ & mascsg : mascpl & 2.47 & 2.69 & $0.000^{*}$ \\
\hdashline feminine : neuter & 3.06 & 2.88 & $0.000^{*}$ & mascsg : femipl & 2.47 & 3.26 & $0.000^{*}$ \\
\hdashline perf : imperf & 2.83 & 2.81 & $0.179^{*}$ & femisg : mascpl & 3.07 & 2.69 & $0.000^{*}$ \\
\hdashline indicat : conditnl & 2.78 & 2.87 & $0.000^{*}$ & femisg : femipl & 3.07 & 3.26 & $0.000^{*}$ \\
\hdashline indicat : imper & 2.78 & 3.27 & $0.000^{*}$ & mascpl : femipl & 2.69 & 3.26 & $0.000^{*}$ \\
\hline
\end{tabular}

* Level of significance lower than $5 \%$ 
Grammatical gender appears to play a stronger role. According to the respondents' estimates, genitive government in negative sentences most often disappears when the complement is feminine $(\bar{x}=3,06)$, less frequently when the complement is neuter (2.88), and least frequently with masculine complements (2.61). The differences are most significant between the masculine and feminine gender $(t=-20.66 ; d f=523$; sig. $=0.000)$, followed by the masculine and neuter $(t=-8.72 ; d f=523 ;$ sig. $=0.000)$, and feminine and neuter gender $(t=5.35 ; d f=524$; sig. $=0.000)$. If number and gender are combined (sg., pl., m., and f. only), the accusative is most often employed instead of the genitive in sentences with feminine complements in the plural $(\bar{x}=3.26)$, followed by feminine complements in the singular (3.07), masculine complements in the plural (2.69), and masculine complements in the singular (2.47).

The lowest occurrence of the genitive of negation in the dual is likely a consequence of its decreasing use. Out of the three numbers, dual is the most marked and least frequent, and has already been lost in some dialects. In general, speakers use it the least and are therefore the most indifferent to its use.

The difference between feminine and masculine complements corresponds to the situation in Russian: the genitive of negation of feminine complements is thus more likely to be replaced with the accusative. As mentioned before, a possible explanation is the avoidance of ambiguity due to identical forms of the genitive singular and accusative plural of $\bar{a}$-stems. Nevertheless, the argument that masculine nouns are exempt from such ambiguities is not convincing. In Slovenian, for example, genitive singular and accusative dual of first declension masculine nouns are identical and can therefore lead to the same ambiguity. In colloquial Slovenian, the sentence nisem videl brata can either mean 'I did not see the brother' (genitive) or 'I did not see the (two) brothers' (accusative). It is much more plausible to trace the source of these differences to the genitive-accusative of the animate masculine nouns in the singular (where genitive government is the only possible option in affirmative and negative sentences). By analogy, this distinctive rection indirectly reinforces and strengthens the genitive of the inanimate complements. ${ }^{30}$

Unlike Russian, Slovenian only uses the genitive-accusative in the singular, which could explain why masculine plural complements are more likely to lose the genitive of negation in Slovenian. The differences between feminine singular and feminine plural complements are less clear. One of the possible (but still questionable) explanations can be based on similar reasoning that some linguists use when explaining different distribution of genitive and accusative in the singular and plural forms of inanimate masculine nouns in Russian. By assuming an opposite direction of influence and an original mandatory genitive government in negative sentences, the

${ }^{30}$ Furthermore, the morphological proximity of neuter and masculine stems on the on hand, and the lack of the neuter genitive-accusative on the other hand explain why neuter complements lose the genitive of negation less frequently than feminine complements and more often than masculine ones. 
accusative might have first started replacing the genitive in the plural because it was identical to the widely used genitive singular.

We have mentioned studies showing that pronouns are the first to lose the genitive of negation, especially nic 'nothing'. Our survey confirmed these findings; out of all second level categories tested, the difference between pronominal $(\bar{x}=3.65)$ and nominal (2.79) complements is the most evident $(t=-22.36 ; d f=522 ; \mathrm{sig} .=0.000)$. Since accusative pronominal complements have appeared in negative sentences already in OCS, we might conclude that genitive government is first lost where it has been the weakest from the beginning. Moreover, the negative pronoun nic is always followed by a negated verb in Slavic languages, therefore an additional negative marker in the form of the genitive of negation might have been deemed unnecessary as early as the Proto-(Balto)-Slavic era.

The survey also confirmed that the accusative is more likely to be the case of long distance complements $(t=-12.74, d f=523$; sig. $=0.000)$, which is the result of a reduced negative particle influence when the object and the finite verb are separated by an infinitive. According to the respondents' estimates, long distance genitive $(\bar{x}=$ 2.82) is thus less frequent than local genitive (3.15) in selected negated sentences.

Remarkably, unlike in Russian, in which the aspect is one of the most significant factors that affect the distribution of the accusative and genitive in negative sentences, imperfective and perfective verbs do not seem to influence the loss or retention of the genitive of negation in Slovenian $(t=1.35 ; d f=523$, sig. $=0.179)$. Mood, on the other hand, appears to follow similar patterns in both languages: the indicative had the lowest average accusative acceptability rate $(\bar{x}=2.78)$, followed by the conditional $(2.87)$ and the imperative (3.27). ${ }^{31}$ Timberlake thought this was the result of the latter two describing potential, nonactual events, in which the affirmative meaning is still possible. In the indicative, the negation is much more certain and stronger. While his reasoning is definitely plausible, another option is to take into consideration that the imperative, an outlier in our survey, is much more often used in informal, spoken language, while the other two moods are relatively more common in the standard language.

\subsubsection{Cluster analysis}

In the final part of the analysis, an effort was made to classify the respondents into groups with similar perceived accusative acceptability grades, so that respondents within individual groups would have as similar grades as possible and that participants of different groups would differ to the largest possible extent.

${ }^{31}$ The differences are most significant between the indicative and the imperative $(t=$ $-16.96 ; d f=523$, sig. $=0.000)$, followed by the conditional and the imperative $(t=-11.03 ; d f$ $=523$, sig. $=0.000)$, and the indicative and the conditional $(t=-3.72 ; d f=523$, sig. $=0.000)$. 
Table 6: Respondents sorted into three groups through $k$-means clustering

\begin{tabular}{|c|c|c|c|c|}
\hline & & & & \multirow[b]{2}{*}{ sig. } \\
\hline & Group A & Group B & Group C & \\
\hline$N$ & 95 & 149 & 95 & \\
\hline Percentage share & $28.0 \%$ & $44.0 \%$ & $28.0 \%$ & \\
\hline meanval (arithmetic mean) & 3.85 & 2.96 & 1.98 & \\
\hline Ljubljana / Central Slovenian varieties & $43.2 \%$ & $51.7 \%$ & $61.1 \%$ & \multirow{10}{*}{0.138} \\
\hline Upper Carniolan dialect group & $5.3 \%$ & $6.7 \%$ & $6.3 \%$ & \\
\hline Lower Carniolan dialect group & $13.7 \%$ & $7.4 \%$ & $7.4 \%$ & \\
\hline Styrian dialect group & $9.5 \%$ & $11.4 \%$ & $10.5 \%$ & \\
\hline Littoral dialect group & $10.5 \%$ & $8.1 \%$ & $10.5 \%$ & \\
\hline Carinthian dialect group & $2.1 \%$ & $1.3 \%$ & $0.0 \%$ & \\
\hline Pannonian dialect group & $9.5 \%$ & $6.7 \%$ & $2.1 \%$ & \\
\hline Rovte dialect group & $2.1 \%$ & $2.7 \%$ & $1.1 \%$ & \\
\hline Other & $1.1 \%$ & $4.0 \%$ & $1.1 \%$ & \\
\hline Slovenian not mother tongue & $3.2 \%$ & $0.0 \%$ & $0.0 \%$ & \\
\hline Primary school (K-8 or K-9) & $1.1 \%$ & $0.7 \%$ & $2.1 \%$ & \multirow{7}{*}{$0.028^{*}$} \\
\hline Vocational high school & $7.5 \%$ & $7.4 \%$ & $4.2 \%$ & \\
\hline Gymnasium (high school) & $22.6 \%$ & $22.1 \%$ & $34.7 \%$ & \\
\hline Higher vocational education & $0.0 \%$ & $7.4 \%$ & $6.3 \%$ & \\
\hline University education - undergraduate & $53.8 \%$ & $51.0 \%$ & $32.6 \%$ & \\
\hline University education - graduate & $15.1 \%$ & $10.1 \%$ & $18.9 \%$ & \\
\hline Other education & $0.0 \%$ & $1.3 \%$ & $1.1 \%$ & \\
\hline Linguists & $33.7 \%$ & $24.3 \%$ & $25.5 \%$ & \multirow{2}{*}{0.252} \\
\hline Non-linguists & $66.3 \%$ & $75.7 \%$ & $74.5 \%$ & \\
\hline Younger than 25 years & $22.6 \%$ & $23.6 \%$ & $31.6 \%$ & \multirow{5}{*}{0.121} \\
\hline $25-35$ years & $55.9 \%$ & $58.8 \%$ & $47.4 \%$ & \\
\hline $35-45$ years & $10.8 \%$ & $6.8 \%$ & $7.4 \%$ & \\
\hline $45-55$ years & $3.2 \%$ & $8.8 \%$ & $10.5 \%$ & \\
\hline 55 years and older & $7.5 \%$ & $2.0 \%$ & $3.2 \%$ & \\
\hline
\end{tabular}

* Level of significance lower than $5 \%$

After each clustering, performed by using the $k$-means clustering method, demographic analyses of clusters were made, and the process was repeated with another number of clusters. Three clusters proved to be the most statistically diverse and meaningful 
grouping. ${ }^{32}$ The resulting three groups were named $\mathrm{A}, \mathrm{B}$, and $\mathrm{C}$ with the first and the third consisting of $28 \%$ and the second of $44 \%$ of all considered respondents. ${ }^{33}$ Participants in group A were the most likely to perceive the accusative complement in negative sentences as more acceptable and frequent (mean value of the variable meanval was $\bar{x}=3.85$ ), while respondents from group $\mathrm{C}$ were the least likely to do so (1.98). The observations of the group B members were between the two other groups (2.96). Table 6 summarizes the findings and shows the demographic structure of each group.

Education is the only demographic variable that is significantly different between the groups A, B, and C. In the first two, there is a higher percentage of respondents who have finished a vocational high school or have undergraduate education. Group C, on the other hand, has a higher share of respondents with gymnasium and graduate education. The implication of this information is questionable, especially when taking into consideration the relatively small number of respondents in some of the subgroups within the three groups. It is thus more adequate to conclude that the findings of the cluster analysis do not confirm any distinct demographic, sociolinguistic groups of Slovenian speakers that would significantly differ in their use of the genitive of negation.

\section{Conclusions}

Genitive government of negated transitive verbs has been characterized by rapidly declining use in daughter languages over the last couple of centuries. Today, it is mandatory only in Slovenian, Polish, and Lithuanian. In Russian, it is optional, while in other Slavic languages and Latvian, it is either considered archaic or extinct.

The construction can be derived from the partitive genitive, which at a certain point acquired an emphatic meaning. Such a meaning was first used as a marker of reinforced negation, with genitive later becoming the only acceptable and unmarked government of negated transitive verbs, spreading also to complements that could originally not have a partitive meaning. This process most likely took place in Proto-Balto-Slavic or in close contact of subsequent Proto-Slavic and (Eastern) Proto-Baltic. The ablative origins theory, on the other hand, does not seem plausible.

Our survey confirmed that the genitive of negation is disappearing in contemporary Slovenian. There does not seem to be any correlation between countability or animacy

${ }^{32}$ When a computer algorithm based on the Schwarz-Bayesian criterion to automatically select the number of groups was used, three groups were formed as well. They only slightly differed in size and average accusative acceptability grades from the three groups obtained with the $k$-means method.

${ }^{33}$ The $k$-means clustering only included the 339 respondents who evaluated the acceptability of the accusative in each of the 52 sentences of the questionnaire. 
of the complement and a greater/lesser likelihood of using the genitive under negation. A genitive object is, however, less likely to be replaced with the accusative form when the negation is emphatic. This reflects (genetically or typologically) the origins of the genitive of negation and has also been observed in some other Slavic languages.

The demographic configuration of the sample should be taken into consideration when interpreting the results, particularly the higher percentage share of speakers from Ljubljana or Central Slovenia region and the relatively low average age of respondents. Nevertheless, the bivariate analyses in general did not show major differences between demographic groups, hence our findings can be deemed a valid reflection of the genitive use in the general population. On average, Styrian dialect group and Central Slovenian varieties seem to better retain the genitive of negation than other dialect groups. Speakers of the Pannonian and Lower Carniolan group on the other hand, seem to replace it with the accusative more often. The differences are generally minor and were statistically significant only in one third of the sentences.

With the genitive of negation being a complex syntactic category, the question remains whether there are additional lurking variables that directly or indirectly affect its incidence and thus the results of the analysis (either by coincidence or as mediator/moderator variable). There are many potential factors that could also be affecting the occurrence of genitive objects under negation, either at a syntactic (e.g., topicalization), morphological (e.g., tense), lexical, or even prosodic level. At the same time, it needs to be emphasized that including additional categories in the analysis would require testing a much higher number of sentences, making such a survey impractical. The only methodological alternative seems to be text corpus analysis, which, on the other hand, does not allow for an optimal insight into the use in the spoken language.

There are other aspects of the genitive of negation that call for additional research, one of them being a thorough analysis of its development in the historical period of those languages that had lost the syntactic rule prior to establishing their modern forms. This, as well as testing potential additional variables that could be affecting the distribution of the genitive vs. accusative government in negative sentences, remains a challenge for future work. Supplementary research could possibly help find more traces of the (former) partitive and emphatic meaning of genitive complements under negation. Namely, the dynamics of declining usage of a linguistic form can answer many questions about the subtle nuances of its grammatical and semantic features, and thus point to its historical origin and evolution. 


\section{References}

Adamovič, J. et al. 1975. Сучасная беларуская літаратурная мова: Марфалогія. Minsk: Vyšejšaja škola.

Bailyn, John F. 2003. Genitive of Negation is Obligatory. Retrieved September 24, 2014, from http://www.sinc.sunysb.edu/Clubs/nels/jbailyn/JFBgenNegOblig.pdf

Balode, Laimute, and Axel Holvoet. 2001. The Latvian Language and Its Dialects. In CircumBaltic Languages. Volume I: Past and Present, ed. by Östen Dahl, and Maria KoptjevskajaTamm, 3-40. Amsterdam: John Benjamins Publishing.

Belić, Aleksandar. 1950. Istorija srpskohrvatskog jezika. Knj. 2, sv. 1, Reči sa deklinacijom. Predavanja Aleksandra Belića. Belgrade: Naučna knjiga.

Błaszczak, Joanna. 2001. Investigation into the Interaction between the Indefinites and Negation. Berlin: Akademie Verlag.

Bohorič, Adam. 1987/1584. Arcticae horulae succisivae: Zimske urice proste. Maribor: Obzorja.

Borschev, Vladimir, and Barbara H. Partee. 1998. Formal and lexical semantics and the genitive in negated existential sentences in Russian. In Formal Approaches to Slavic Linguistics 6: The Connecticut Meeting 1997, ed. by Željko Bošković, Steven Franks, and William Snyder, 75-96. Ann Arbor: Michigan Slavic Publications.

Božič, Ana, Nataša Komac, Petra Tomažin, and Tina Verovnik. 1998. Rodilnik in tožilnik v zanikanju. Blapis: časopis študentov jezikoslovja na Filozofski fakulteti Univerze v Ljubljani 2(2): 2-10.

Campbell, Lyle. 1997. Typological and Areal Issues in Reconstruction. In Linguistic Reconstruction and Typology, ed. by Jacek Fisiak, 49-72. Berlin: Mouton de Gruyter.

Chlupíková, Katarína. 2011. Priamy predmet v litovčine v porovnaní so slovenčinou. Bakalárska diplomová práca. Brno: Masarykova univerzita, Filozofická fakulta. Retrieved October 30, 2014, from http://is.muni.cz/th/342306/ff_b/bakalarska_praca.txt

Collopy, Erin M. 1998. A Quantitative and Lexical Analysis of Genitive/Accusative Variation in Russian. A dissertation submitted in partial fulfilment of the requirements for the degree of Doctor of Philosophy. Seattle: University of Washington.

Cvetko Orešnik, Varja. 1998. Kmetodologiji preučevanja baltoslovansko-indoiranskih jezikovnih odnosov. Prvi del. Ljubljana: ZRC SAZU.

Endzelin, Jānis. 1944. Altpreussische Grammatik. Riga: Verlag Latvju Grāmata.

Freising Manuscripts: Digital Edition. 2007. Ed. by Matija Ogrin. Retrieved December 27, 2014, from http://nl.ijs.si/e-zrc/bs/index-en.html

Gāters, Alfrēds. 1993. Lettische Syntax: die Dainas. Frankfurt am Main: Peter Lang.

Gortan-Premk, Darinka. 1961. Padež objekta u negativnim rečenicama u savremenom srpskohrvatskom književnom jeziku. Naš jezik, Nova serija 12: 130-148.

Guiraud-Weber, Marguerite. 2003. Еще раз о русском генитиве отрицания: взгляд со стороны. Russian Linguistics 27(3): 401-408.

Hrovat, Ladislav. 1862. Slovenski genitiv. Programm des kaiserl. königl. Gymnasiums zu Neustadtl am Schlusse des Schuljahres 1862. Ljubljana: Ign. v. Kleinmayr and Fedor Bamberg.

Il'čenko, Olga. 2010. Genitivus negationis в славянских языках: к проблеме генезиса приглагольного родительного падежа. In $I V$ Международный конгресс исследователей русского языка »Русский язык: исторические судьбы и современность«, 62-63. Moscow: MGU.

Ilc, Gašper. 2008. O zanikanju in nikalnici v slovenščini. Jezik in slovstvo 53(2): 65-79. 
Ilc, Gašper. 2009. Optionality of the Genitive (of Negation) in Slovene. Retrieved November 7 , 2014, from http://www.uni-potsdam.de/fdsl_8/abstracts/gasper.pdf

Ivšić, Stjepan. 1970. Slavenska poredbena gramatika. Zagreb: Školska knjiga.

Jonke, Ljudevit. 1952. Nekoliko kraćih odgovora. Jezik: časopis za kulturu hrvatskoga književnog jezika 1(4): 123-124.

Kagan, Olga. 2007. Property-Denoting NPs and Non-Canonical Genitive Case. In Proceedings from Semantic and Linguistic Theory XVII, ed. by Tova Friedman, and Masayuki Gibson, 148-165. Ithaca: Cornell University.

Kagan, Olga. 2010. Genitive objects, existence and individuation. Russian Linguistics 34(1): 17-39.

Kamp, Andreas. 2006. Der Genitiv der Verneinung im Slavischen und Baltischen. In Studia Philologica Slavica. Festschrift für Gerhard Birkfellner zum 65. Geburtstag gewidmet von Freunden, Kollegen und Schülern, ed. by Bernhard Symanzik, 267-276. Berlin: LIT Verlag.

Kaučič-Baša, Majda. 1982. Rodilnik zanikanja. Slavistična revija 30(1-4): 305-321.

Kiparsky, Paul. 1998. Partitive Case and Aspect. Retrieved December 7, 2014, from http://web. stanford.edu/ kiparsky/Papers/wuppertal.pdf

Korn, David. 1967. Genitive or Accusative after Negation in Russian. The Slavic and East European Journal 11(4): 442-449.

Krasovitsky, Alexander, Matthew Baerman, Dunstan Brown, and Greville G. Corbett. 2011. Changing semantic factors in case selection: Russian evidence from the last two centuries. Morphology 21(3-4): 573-592.

Kulikov, Leonid. 2006. Case Systems in a Diachronic Perspective. In Case, Valency and Transivity, ed. by Leonid Kulikov, Andrej Malchukov, and Peter de Swart, 23-48. Amsterdam: John Benjamins Publishing.

Leisio, Larisa. 2004. Russian Case Forms Used by Finns of Russian-Speaking Descent. Virittaja 108(2): 162-199.

Lukašanec, Aljaksandr, Mikalaj Prigodzič, and Lidzija Sjameška. 1998. Belaruskaja mova. Opole: Uniwersytet Opolski - Instytut Filologii Polskiej.

Malcius Bulota, Vilia. 1980. Changes in the Usage of the Genitive Case in Lithuanian. A thesis submitted to the Faculty of Graduate Studies and Research in partial fulfilment of the requirements for the degree of Master of Arts. Montreal: McGill University.

Mathiassen, Terje. 1996. A Short Grammar of Lithuanian. Columbus: Slavica Publishers.

Meillet, Antoine. 1897. Recherches sur l'emploi du génitif-accusatif en vieux-slave. Paris: Ministère de l'instruction publique.

Menac, Antica. 1979. Slavenski genitiv u suvremenom hrvatskom književnom jeziku. Jezik: časopis za kulturu hrvatskoga književnog jezika 26(3): 65-76.

Merše, Majda. 2000. Primerjava glagolov pri slovenskih protestantskih piscih in Svetokriškem. In Zbornik o Janezu Svetokriškem, ed. by Jože Pogačnik, and Jože Faganel, 209-227. Ljubljana: ZRC SAZU.

Metelko, Franc Serafin. 1825. Lehrgebäude der slowenischen Sprache im Königreiche Illyrien und in den benachbarten Provinzen: nach dem Lehrgebäude der böhm. Sprache des Hrn. Abbé Dobrowsky. Ljubljana: Leopold Eger.

Miklošič, Franc. 1883. Vergleichende Grammatik der Slavischen Sprachen. Vierter Band: Syntax. Vienna: Wilhelm Braumüller.

Napoli, Maria. 2010. The Case for the Partitive Case: the Contribution of Ancient Greek. Transactions of the Philological Society 108(1): 15-40.

Orešnik, Janez. 1992. Udeleženske vloge v slovenščini. Ljubljana: SAZU. 
Pirnat, Žiga. 2011. Iztožilniški rodilnik ob zanikanih prehodnih glagolih v baltoslovanščini. Diplomsko delo. Ljubljana: Filozofska fakulteta.

Pohlin, Marko. 1768. Kraynska grammatika, das ist: Die kraynerische Grammatik, oder Kunst die kraynerische Sprache regelrichtig zu reden, und zu schreiben. Ljubljana: P. Marcus, a S. Antonio Pad.

Przepiórkowski, Adam. 2000. Long Distance Genitive of Negation in Polish. Journal of Slavic Linguistics 8: 151-189.

Rusanovskij, Vitalij M., Mihail A. Žovtobrjuh, E. G. Gorodenskaja, and A. A. Griščenko. 1986. Украинская грамматика. Kiev: Naukova dumka.

Schuster-Šewc, Heinz. 2000. Das Sorbische im slawischen Kontext. Ausgewählte Studien. Bautzen: Domowina-Verlag.

Senn, Alfred. 1970. Slavic and Baltic Linguistic Relations. In Donum Balticum, ed. by Velta Rūķe-Dravina, 485-494. Stockholm: Almqvist \& Wiksell.

Skeat, Walter W. 1883. Gospel of Saint Mark in Gothic According to the Translation Made by Wulfila in the Fourth Century. London: Oxford University Press.

Szemerényi, Oswald. 1980. Einführung in die vergleichende Sprachwissenschaft. Darmstadt: Wissenschaftliche Buchgesellschaft.

Šahmatov, Aleksej. 1963. Синтаксис русского языка. Haag: Mouton \& Co.

Šewc, Hinc. 1968. Gramatika hornjoserbskeje rěče. 1. zwjazk: fonematika a morfologija. Budyšin: Ludowe nakładnistwo Domowina.

Timberlake, Alan. 1975. Hierarchies in the Genitive of Negation. The Slavic and East European Journal 19(2): 123-138.

Toporišič, Jože. 2004. Slovenska slovnica. Maribor: Obzorja.

Uhlár, Rudo. 1933. Záporný genitív v spisovnej slovenčine. In Sborník na počest' Jozefa Škultétyho, 607-626. Turčiansky Svätý Martin: Matica Slovenská.

Vaillant, André. 1977. Grammaire comparée des langues slaves. Tome V: La Syntaxe. Paris: Editions Klincksieck.

Vince, Jasna. 2008. Uzmak genitiva izravnoga objekta. Slovo: časopis Staroslavenskoga zavoda u Zagrebu 56-57: 615-626.

Vondrák, Václav. 1928. Vergleichende Slavische Grammatik. II. Formenlehre und Syntax. Göttingen: Vandenhoeck \& Ruprecht.

Zinkevičius, Zigmas. 1998. The History of the Lithuanian Language. Vilna: Mokslo ir enciklopedijų leidybos institutas.

Prispelo aprila 2015, sprejeto maja 2015

Received April 2015, accepted May 2015 


\section{Genesis of the Genitive of Negation in Balto-Slavic and Its Evidence in Contemporary Slovenian}

Genitive of negation is a Balto-Slavic syntactic rule that governs the transformation of accusative complements of transitive verbs or subjects of existential constructions in positive sentences to genitive complements in negative sentences. At present, this change is mandatory in Slovenian, Polish, and Lithuanian.

In these three languages, objects of transitive verbs always change from accusative to genitive when the verb in question is negated. This includes long distance genitive and dual objects. Rare exceptions can be found in negative constructions with correlative conjunctions not only - but also, in which Slovenian allows both cases, and Lithuanian only uses accusative. Unlike Lithuanian, Slovenian is experiencing a rapid decline of genitive of negation in everyday speech. The process can be observed since some of the oldest written sources and grammar books of Slovenian.

In Russian, the genitive of negation is only mandatory in fixed expressions, in connection with the verb imet' 'to have' and under emphatic negation. In all other instances, it is optional and typically gives way to accusative. The process of its syntactic decay, which is still taking place, shows several noteworthy features in the alternating usage of accusative and genitive complements. According to Timberlake, the genitive is more common when the object is less individuated, i.e., semantically or grammatically refers to common, abstract, mass, inanimate, indefinite, etc. reality. All these parameters or hierarchies seem to reflect a historical partitive meaning of genitive of negation.

In other Slavic languages, direct objects in the genitive under negation have become obsolete or are deemed archaic. Among Baltic languages, it was once present in Latvian, where it is not used anymore. Old Prussian records show a handful of isolated cases that are unlikely to be a sign of a general rule. Occurrences in Gothic, Old High German, Ancient Greek, and even French have no plausible genetic connection to the Balto-Slavic genitive of negation. Most of the time, they can be explained as sporadic instances of partitive genitive that may have been used as an additional negative (or even aspect) marker. Nonetheless, while a typological parallel at best, they are not an independent syntactic category with mandatory genitive rection triggered by negation as is the case in Balto-Slavic. Finnish accusative-to-partitive transformation in negated sentences seems to be a typological parallel as well, although an adstrate influence of Balto-Slavic languages (or vice versa) cannot be dismissed.

The genesis of the genitive of negation is most often traced to an earlier ablative or partitive genitive. While the first option is less plausible, the second one is relatively well supported; however, it does not offer a convincing explanation of the transition from the original partitive category (at a semantic, lexical level) to a syntactic category (genitive government). In the article, we present a diachronic model of the origins and subsequent development of the genitive of negation in five stages. The 
construction is conceived as the successor of the partitive genitive that at a certain point acquired an emphatic meaning. At first, such expressive negation served as a reinforcement of negation, eventually becoming an additional negative marker. This later became mandatory and spread to complements that could originally not have carried partitive meaning. With such widespread use, the genitive of negation lost its emphatic and partitive meaning evolving into an independent syntactic rule that was no longer (semantically) linked to verbal action, becoming (syntactically) tied to negation instead.

Our survey confirmed that the genitive of negation is disappearing in contemporary Slovenian. There does not seem to be any correlation between countability or animacy of the complement and a greater/lesser likelihood of using the genitive under negation in spoken language. A genitive object is, however, less likely to be replaced with the accusative form when the negation is emphatic. Dual seems to be most affected by accusative leveling in negative sentences, followed by singular and plural. Unlike masculine objects, feminine complements are much more likely to appear in the accusative instead of the genitive, which is possibly a result of not maintaining the same genitive-accusative proximity in singular forms as (animate) masculine nouns. As is the case in other Slavic languages, including Old Church Slavonic, accusative complements of negated verbs in Slovenian are much more frequent in pronouns. Furthermore, the long distance genitive of negation is significantly more likely to appear in the accusative than its corresponding local construction.

On average, Styrian dialect group and Central Slovenian varieties seem to better retain the genitive of negation than other dialect groups. Speakers of the Pannonian and Lower Carniolan group on the other hand, seem to replace it with the accusative more often. The differences are generally minor and were statistically significant only in one third of the sentences included in the survey.

The research proved that the historical emphatic markedness of genitive objects in negative constructions is still reflected at a syntactic level today in spite of its historical neutralization in the process of establishing the genitive of negation. While we have shown that the genitive of negation is better preserved in sentences with emphatic negation in Slovenian, similar observations can be found in the literature about Russian, Serbian and Croatian, and until recently, Czech and Slovak. Obviously, this might not necessarily be an inherited syntactic feature, but possibly a cognitive sense of (subconsciously) relating emphatic negation to the genitive, i.e., a typological parallel to the original use. 


\section{Geneza rodilnika zanikanja v baltoslovanščini in njene sledi v sodobni slovenščini}

Rodilnik zanikanja je baltoslovanski skladenjski pojav, s katerim poimenujemo prestavo tožilniškega dopolnila prehodnih glagolov ali osebka v eksistencialnih konstrukcijah v rodilnik, kadar je glagolsko dejanje zanikano. Danes je ta prestava obvezna v slovenščini, poljščini in litovščini.

$\mathrm{V}$ teh treh jezikih se mora tožilniški neposredni predmet ob zanikanem glagolu prestaviti v rodilnik vedno, tudi ob nedoločniku (kot tako imenovani oddaljeni rodilnik zanikanja) in kadar gre za dvojni predmet. Redka izjema so priredne zveze ne le-temveč tudi, v katerih slovenščina dopušča oba sklona, litovščina pa uporablja izključno tožilnik. Za razliko od litovščine, $\mathrm{v}$ kateri je rodilnik zanikanja trdno zasidran, se sicer ta $\mathrm{v}$ pogovorni slovenščini pospešeno izgublja. Ta proces je opaziti že v starejših pisnih virih in slovnicah slovenskega jezika.

$\mathrm{V}$ ruščini je raba rodilnika zanikanja namesto tožilnika obvezna le v stalnih besednih zvezah, ob zanikanem glagolu imet' in v primeru poudarjenega zanikanja, sicer je fakultativna. V procesu opuščanja te konstrukcije, ki še vedno traja, lahko opazimo številne zakonitosti pojavljanja tožilnika in rodilnika ob zanikanih prehodnih glagolih. Rodilnik se po Timberlaku pogosteje pojavlja pri dopolnilih z nižjo stopnjo individualizacije, ki označujejo obče, abstraktno, neštevno, neživo, nedoločeno, neopredeljeno ipd. Vse te hierarhije zrcalijo historični partitivni pomen rodilnika zanikanja.

V drugih slovanskih jezikih je rodilnik zanikanja skoraj povsem izginil ali pa ga slovnice omenjajo zgolj kot arhaično obliko. Od baltskih jezikov ga je poleg litovščine nekoč poznala tudi latvijščina, ki pa ga danes več ne uporablja. V ohranjenih staropruskih virih zasledimo le peščico osamljenih primerov, ki ne kažejo na obvezno pravilo. Primeri iz gotščine, stare visoke nemščine, stare grščine in celo francoščine nimajo neposredne povezave $\mathrm{z}$ baltoslovanskim rodilnikom zanikanja. Pri njih gre večinoma za sporadične pojave partitivnega rodilnika, ki sicer lahko služi kot dodatni označevalec zanikanja (ali celo glagolskega vida), a tovrstni pojavi rodilnika niso enaki samostojni skladenjski kategoriji z obvezno rodilniško rekcijo, vezano na nikalnico, kot je primer v baltoslovanščini. Finska obvezna prestava tožilniških predmetov v zanikanih stavkih v partitiv je verjetno prav tako tipološka vzporednica, čeprav adstratnega vpliva baltoslovanskih jezikov (ali obratno) ni mogoče povsem izključiti.

Izvor rodilnika zanikanja jezikoslovci najpogosteje povezujejo bodisi z ablativom bodisi s partitivnim rodilnikom. Medtem ko je prva možnost zelo malo verjetna, je druga sorazmerno dobro utemeljena, ne ponudi pa zadovoljive razlage prehoda prvotne oblikoslovne partitivne kategorije (na semantični ravni) v skladenjsko (rodilniška rekcija). V članku smo zato predlagali diahroni model izvora in razvoja iztožilniškega rodilnika ob zanikanih prehodnih glagolih, ki temelji na petih fazah. Model razlaga rodilnik zanikanja kot naslednik partitivnega rodilnika, ki je v določenem obdobju pridobil pomen emfatičnosti. Tako čustveno poudarjeno zanikanje je najprej 
služilo kot okrepitev zanikanja in sčasoma postalo dodaten označevalec nikalnega pomena. Pozneje je to postal edini sprejemljivi način zanikanja in se razširil tudi na predmete, ki prvotno niso mogli nastopati v partitivnem rodilniku. S tako razširjeno rabo se je izgubil pomen emfatičnosti in partitivnosti, rodilnik zanikanja pa je postal samostojna kategorija, ki ni bila več (pomensko) vezana na glagol, temveč (skladenjsko) na nikalnico.

Naša raziskava je potrdila, da rodilnik zanikanja v sodobni slovenščini izginja. Kategoriji števnosti in živosti dopolnila statistično značilno ne vplivata na pogostost rabe rodilnika ob zanikanih prehodnih glagolih v govorjenem jeziku. Pač pa se rodilnik ohranja dlje v stavkih s poudarjenim zanikanjem. Tožilnik najhitreje zamenjuje rodilnik v dvojini, ki ji sledita ednina in množina. Dopolnila ženskega spola opustijo rodilnik precej pogosteje kot dopolnila moškega spola, kar je verjetno posledica tega, da prva ne poznajo bližine rodilniških in tožilniških oblik, kot jo najdemo pri samos-

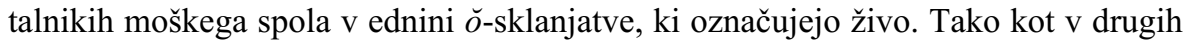
slovanskih jezikih in že v stari cerkveni slovanščini je tožilnik ob zanikanih glagolih pri zaimkih precej pogostejši kot pri samostalnikih. Prav tako zamenja rodilnik v nedoločniških konstrukcijah prej kot v bližnjem predmetu.

V povprečju najmanj zaznavajo vdor tožilnika v zanikane konstrukcije v štajerski narečni skupini in ljubljanskih/osrednjeslovenskih govorih, največ pa v panonski in dolenjski skupini. Razlike so večinoma majhne in so bile statistično značilne le pri tretjini stavkov, vključenih v vprašalnik.

Raziskava je pokazala, da se emfatična zaznamovanost rodilniških predmetov $\mathrm{v}$ zanikanih konstrukcijah danes še vedno zrcali na skladenjski ravni, kljub njeni historični nevtralizaciji v procesu razvoja rodilnika zanikanja. Ugotovili smo, da je leta precej bolje ohranjen $\mathrm{v}$ stavkih $\mathrm{z}$ emfatičnim zanikanjem $\mathrm{v}$ slovenščini, podobna opažanja pa najdemo v literaturi tudi na primeru ruščine, srbščine in hrvaščine ter, do nedavnega, češčine in slovaščine. To seveda ni nujno neposredno podedovana skladenjska značilnost, lahko pa gre za kognitivno (zavedno ali nezavedno) povezovanje emfatičnega zanikanja $\mathrm{z}$ rodilnikom in torej tipološko vzporednico izvorne rabe. 